\title{
Effects of Dietary Food Components on Cognitive Functions in Older Adults
}

\author{
Hitoshi Ozawa (D), Taiki Miyazawa (D) and Teruo Miyazawa *(D) \\ New Industry Creation Hatchery Center (NICHe), Tohoku University, Sendai 980-8579, Japan; \\ hitoshi.ozawa.b8@tohoku.ac.jp (H.O.); taiki.miyazawa.b3@tohoku.ac.jp (T.M.) \\ * Correspondence: teruo.miyazawa.a7@tohoku.ac.jp; Tel.: +81-22-795-4307
}

check for updates

Citation: Ozawa, H.; Miyazawa, T.; Miyazawa, T. Effects of Dietary Food Components on Cognitive Functions in Older Adults. Nutrients 2021, 13, 2804. https://doi.org/10.3390/ nu13082804

Academic Editors: Anna Picca, Riccardo Calvani and Beatrice Arosio

Received: 26 July 2021

Accepted: 13 August 2021

Published: 16 August 2021

Publisher's Note: MDPI stays neutral with regard to jurisdictional claims in published maps and institutional affiliations.

Copyright: (c) 2021 by the authors. Licensee MDPI, Basel, Switzerland. This article is an open access article distributed under the terms and conditions of the Creative Commons Attribution (CC BY) license (https:/ / creativecommons.org/licenses/by/ $4.0 /)$.

\begin{abstract}
Population aging has recently been an important issue as the number of elderly people is growing worldwide every year, and the extension of social security costs is financially costly. The increase in the number of elderly people with cognitive decline is a serious problem related to the aging of populations. Therefore, it is necessary to consider not only physical care but also cognitive patterns in the future care of older adults. Since food contains a variety of bioactive substances, dietary patterns may help improve age-related cognitive decline. However, the relationship between cognitive function and individual food components remains ambiguous as no clear efficacy or mechanism has been confirmed. Against this background, this review summarizes previous reports on the biological process of cognitive decline in the elderly and the relationship between individual compounds in foods and cognitive function, as well as the role of individual components of food in cognitive function, in the following order: lipids, carotenoids, vitamins, phenolic compounds, amino acids, peptides, and proteins. Based on the research presented in this review, a proper diet that preserves cognitive function has the potential to improve age-related cognitive decline, Alzheimer's disease, and Parkinson's disease. Hopefully, this review will help to trigger the development of new foods and technologies that improve aging and cognitive functions and extend the healthy life span.
\end{abstract}

Keywords: aging; brain lipids; cognitive function; dietary food components; phospholipids; polyphenols; older adults; oxidative stress; reactive oxygen species; vitamins

\section{Introduction}

All countries worldwide are on the track of a super aging society in the current era. The global population aged over 60 years has doubled in the last 30 years and is expected to double again by 2050 [1]. Japan has the highest ratio of elderly people over 65 years of age globally, as well as the highest life expectancy and healthy life expectancy as reported by the Ministry of Health, Labour and Welfare (MHLW). However, the aging of the population leads to high financial costs due to the extension of social security costs and stagnant economies, and the number of elderly people with dementia increases at the same time. The World Health Organization reported approximately 50 million people with dementia worldwide, with almost 10 million new cases occurring each year [2]. The importance of the issue of cognitive aging was reported [3], and many studies examined predictors of nursing home placement in the elderly [4]. The loss of cognitive function takes away independence and can significantly affect family members [5]. Therefore, it is necessary to consider not only physical care but also cognitive patterns in the future care of older adults. Preserving cognitive function maintains independence in older adults, resulting in major social and financial benefits. The relationship between dietary patterns, dementia, and Parkinson's disease (PD) has been widely debated to date [6,7]. Daily dietary consumption can be an important factor in maintaining cognitive function. Nutritional research aimed at maintaining healthy cognitive and metabolic functions often focused on individual food components. Foods and nutrients were identified that may prevent cognitive decline, including fruits, vegetables, fish, monounsaturated fats, polyunsaturated 
fats, and antioxidants. The association between dietary patterns, cognitive function, and metabolic syndrome was reported in older adults [8]. For example, the Mediterranean diet is known to reduce the risk of cardiovascular disease, cancer, and diabetes, and was recently associated with better cognitive function in the elderly population [9]. Furthermore, cognitive dysfunction associated with metabolic syndrome was reported [10], and the effects of metabolic syndrome on cognitive performance in adults during exercise were also reported [11]. Therefore, the development of functional foods for disease prevention is of great importance in the transition of disease properties. However, the relationship between cognitive function and individual food components remains ambiguous, as no clear efficacy or mechanism has been confirmed. Against this background, this review summarizes previous reports on the biological process of cognitive decline in the elderly and the relationship between individual compounds in foods and cognitive function, and describes the role of individual food components in cognitive function.

\section{Method}

To carry out the literature search, Google Scholar, Pubmed and Web of Science were employed. The search was based on key words such as aging, Alzheimer's disease, amino acid, antioxidants, brain, CL-HPLC, carotenoid, cholesterol, cognitive decline, cognitive function, curcumin, dementia, dietary, elderly people, fatty acid, food, free radical theory, lipid peroxidation, luminol, older adult, oxidation, oxidative stress, Parkinson's disease, peptide, phenolic compound, phospholipid, plasmalogen, polyphenol, protein, reactive nitrogen species, reactive oxygen species and vitamin.

\section{Biological Reactions Associated with Aging}

\subsection{Reactive Oxygen Species, Reactive Nitrogen Species and Free Radical Theory}

The involvement of free radicals in cognitive decline and aging has been widely recognized and discussed. Free radicals are universally produced during aerobic cell metabolism. In the body, antioxidant systems work against the free radicals generated to maintain homeostasis. However, due to aging or disease, when the antioxidant system of the body does not work properly or is overexposed to reactive oxygen species (ROS), the major components of the cells, such as lipids [12], proteins [13,14], and DNA [15-17], are oxidatively damaged. Oxidative damage to cells and tissues caused by ROS is considered to be reduced to some extent by the body's enzymatic and non-enzymatic antioxidant defense systems, but the "free radical theory" was proposed to suggest that oxidative damage may outweigh this reduction $[18,19]$.

In general, ROS include singlet oxygen (specifically the ${ }^{1} \Delta_{g}$ state), superoxide anions, hydrogen peroxide, and hydroxyl radicals. The ground state of the oxygen molecule is the ${ }^{3} \Sigma_{g}^{-}$state, and there exists a ${ }^{1} \Delta_{g}$ state and a ${ }^{1} \Sigma_{g}^{+}$state in the excited state (Figure 1) because the orbital energies of each $\pi$ orbital (two bonding orbitals and two antibonding orbitals) degenerate in homonuclear diatomic molecules. It is considered that only the ${ }^{1} \Delta_{g}$ state is related to the reaction with other compounds because the energy of the ${ }^{1} \Sigma_{g}^{+}$state is higher than that of the ${ }^{1} \Delta_{g}$ state and transition to the ${ }^{1} \Delta_{g}$ state occurs. Meanwhile, the ground state of oxygen molecules can easily become super oxide anions because the ground state of the oxygen molecule is biradical. Super oxide anions are monoradicals because of the lone pair electrons. Superoxide anions are produced in various biological systems. Singlet molecular oxygen and hydroxyl radicals, which have high reactivity, are produced from superoxide anions. Hydrogen peroxide is produced by the two-electron reduction of triplet molecular oxygen. More chemically unstable ROS tend to be more reactive. 


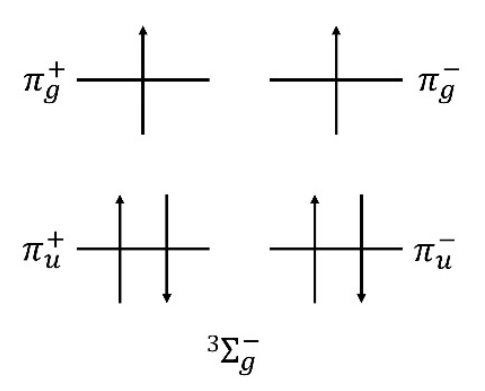

Ground state


Excited states

Figure 1. Electron configuration of the $\pi$ orbitals of the oxygen molecule.

ROS cause cumulative oxidative stress to neural tissue in the brain, resulting in significant impairment of cognitive function, such as Alzheimer's disease (AD), PD, and aging. Antioxidants are expected to be effective in the reduction in oxidative damage caused by free radicals, the removal of ROS or its precursors, and the binding to metal ions that is required to catalyze ROS production [20]. In particular, the supply of antioxidant food components to the body has attracted attention for its potential to inhibit the progression and onset of $\mathrm{AD}, \mathrm{PD}$, and aging, and the importance of daily meals has been discussed.

Moreover, it is known that nitric oxide plays an important role as a cell-signaling molecule, anti-infective agent and antioxidant [21]. Nitric oxide and its derivatives, such as nitrosothiols, peroxynitrite, nitronium cation and nitrogen dioxide, are called reactive nitrogen species (RNS) [21-23]. Nitric oxide is produced within cells by the actions of a group of enzymes called nitric oxide synthases. It is able to form other reactive intermediates, which could have an effect on protein function and on the function of the entire organism. These reactive intermediates can trigger nitrosative damage on biomolecules and may lead to age-related diseases due to the structural alteration of proteins, the inhibition of enzymatic activity, and interferences in regulatory function [22]. Furthermore, it is suggested that the modulatory effects exerted by ROS and RNS on ion channel proteins might have a relevant role in neuronal cell survival or death but more work is required to establish the possible involvement of ion channels and of their modulation by ROS and RNS as important mechanisms of the aging process [23].

\subsection{Lipid Peroxidation}

Research on lipid peroxidation in food deterioration, lipid nutrition, and age-related diseases has gained significant attention in terms of improving societal health and longevity [24]. In 1988, Miyazawa discovered that phospholipid hydroperoxides, which are the first oxidized form of membrane phospholipids, are present in the human body [25]. In the main components of foods and organisms (lipids, proteins, and carbohydrates), lipids are the most reactive oxygen molecules. The resonance of the $\pi$ bond stabilizes radicals generated by hydrogen atom transfer in lipids, and lipid hydroperoxides are produced by the reaction of lipid radicals and ROS. The free radical peroxidation of lipids by singlet oxygen is shown in Figure 2A. Elucidating the formation of lipid peroxides due to oxidative stress is important not only for food quality, atherosclerosis, and cancer, but also for the suppression of aging. $\mathrm{AD}$ is the most common type of cognitive impairment, and in recent years, many studies have reported oxidative changes in the blood of AD patients [26-31]. The blood of patients with $\mathrm{AD}$ has been reported to have a higher concentration of phospholipid hydroperoxide-rich erythrocytes (aged erythrocytes) than that of healthy individuals. Aged erythrocytes are believed to be one of the causes of the onset and progression of AD because they can lead to insufficient oxygen supply and the deterioration of blood rheology. It is believed that high concentrations of amyloid $\beta$ accumulate in the brain of 
patients with $\mathrm{AD}$ and cause oxidative stress in neurons, some of which are released into the bloodstream and adhere to erythrocyte cell membranes. Amyloid $\beta$ attached to the erythrocyte membrane promotes lipid peroxidation in the cell membranes [32]. Amyloid $\beta 40$ and amyloid $\beta 42$ attached to human erythrocytes were quantified; their adhesion was reported to increase with age, and there is a positive correlation between amyloid $\beta$ attached to human erythrocytes and lipid hydroperoxides in erythrocyte membranes [33]. The appearance of oxidized lipoproteins such as low-density lipoprotein and high-density lipoprotein due to aging is also related to pathological conditions such as hyperlipidemia, atherosclerosis, myocardial infarction, and stroke [34,35].

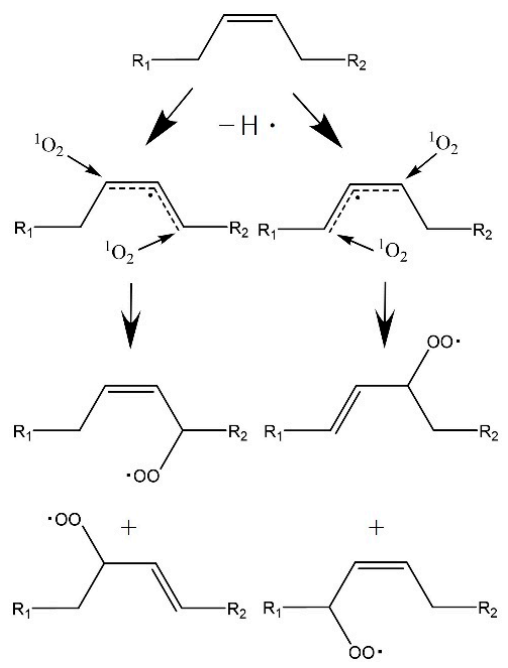

(A)

Lipid hydroperoxides (R-OOH)

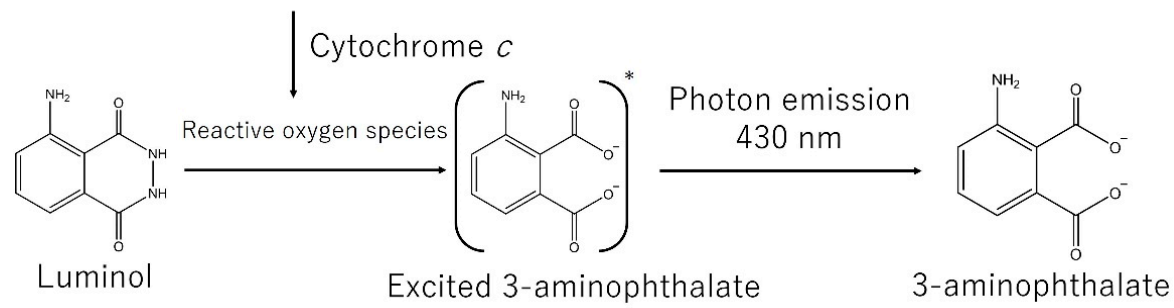

(B)<smiles>O=C1CCCCC1CO</smiles>
Luminol<smiles>Nc1cccc(C(=O)O)c1C(=O)O</smiles>
3-aminophthalate<smiles>Nc1cccc2c(=O)[nH][14c](O)cc12</smiles>

Di-negative ion
勧

Cyclic peroxide<smiles>COC1=c2cccc(N)c2=C([O-])OO1</smiles><smiles></smiles>

Conical intersection<smiles>CCOC(=O)c1c(CC)ccc(CC)c1C(=O)O</smiles>

Excited 3-aminophthalate

(C)

Figure 2. Free radical peroxidation of lipid by singlet oxygen (A) and chemiluminescence reaction of luminol with cytochrome $c$ and lipid hydroperoxide (B) and proposed reaction scheme of luminol reaction $(\mathbf{C})$. * indicates the excited state. Modified from $[36,41,42]$ with permission from Elsevier and the American Chemical Society. 
Miyazawa et al. developed a chemiluminescence high performance liquid chromatography (CL-HPLC) system, which enabled the detection of phosphatidylcholine hydroperoxide $(\mathrm{PCOOH})$ in biological samples [25,36,37]. This method uses luminol (5-amino-2,3dihydro-1,4-phthalazinedione) $[38,39]$ and detects photon emission during the oxidation of luminol by the reaction of lipid hydroperoxides and cytochrome $c$ (Figure 2B) [36,40]. The proposed reaction scheme for the luminol reaction is shown in Figure 2C [41,42]. Dinegative ions and cyclic peroxide structures exist as intermediates in the luminol reaction. The intersystem crossing of 3-aminophthalate from the lowest triplet state to the lowest singlet excited state has been proposed in an earlier study [41], but it has been proposed, in theoretical calculations, that the conical intersection between the ground state and the singlet excited state, on the potential energy surface of the reaction process from the cyclic peroxide structure to 3-aminophthalate, controls luminol chemiluminescence [42]. Several reports have confirmed the reduction in lipid peroxides in human organisms when foods are ingested using the CL-HPLC method. Miyazawa et al. reported that daily intake of chlorella tablets ( $8 \mathrm{~g}$ chlorella/day/person) for more than 1 month suppressed the appearance of aged erythrocytes in the blood of senior Japanese participants [43]. Burdeos et al. reported that 3 weeks of ingestion of rice bran oil rich in tocotrienol ( 5 or $10 \mathrm{mg}$ of tocotrienol/day) reduced triglyceride and phospholipid hydroperoxide levels in the blood and liver of F344 rats [44]. However, the detailed mechanism by which such foods reduce phospholipid peroxidation in vivo is still unclear. In recent years, new analytical methods for lipid peroxidation in vivo involving LC-MS/MS were established one after another, and integrated elucidation of the mechanism of lipid peroxidation using such analytical methods is expected [24]. Recently, ferroptosis, which is a newly identified regulated form of cell death correlated with the etiopathogenesis of PD and AD, was considered to play a major role in neurodegenerative disease [45]. Ferroptosis is regulated mainly via iron homeostasis, glutathione metabolism and lipid peroxidation. Hence, the importance of the association between lipid peroxidation and cognitive impairment should increase in future studies.

\section{Role of Functional Food Compounds in Cognitive Performance}

\subsection{Major Phospholipids}

Phospholipids have a hydrophobic tail containing two fatty acids and a hydrophilic head containing a polar group. Glycerophospholipids (GPLs) are key components of cell membranes. They are the major source of long-chain polyunsaturated fatty acids (PUFA) and the reservoir of signaling molecules. Glycerophospholipids in cell membranes mainly include phosphatidylcholine (PC), phosphatidylethanolamine (PE), phosphatidylserine (PS), and phosphatidylinositol (PI) [46]. They can be derived from de novo synthesis or resynthesis. For example, in enterocytes, dietary GPL is hydrolyzed to free fatty acids and lysophospholipids [47-49]. PC and PS were investigated for their roles in brain development, with some positive effects on cognitive enhancement in preclinical models $[50,51]$ and mixed results in clinical studies [52,53]. Sphingomyelin (SM) is a sphingophospholipid that is classified as either a phospholipid or a sphingolipid. SM is particularly rich in the myelin sheath of the central nervous system [54,55], and due to its role in myelin integrity [56] and axonal maturation [57], SM was implicated in several different cognitive disorders [58]. The effects of aging on the content, composition, and synthesis of SM in the central nervous system were reported [59].

Brain vulnerability increases rapidly with age and its deterioration has been elucidated in a variety of ways. One feature of the aging process is the modification of the properties of the brain membrane [60]. It has been observed that the composition of lipid fatty acids in the brain membrane and, consequently, the fluidity of the membrane change with increasing age [61]. Phospholipids are a key factor in their properties because cell membranes are mainly composed of phospholipids. Studies carried out in rats up to 18 months of age indicated that the synthesis of phospholipids such as PC and PE in the brain decreased during aging $[62,63]$. Furthermore, it has been clarified that the main phospholipid of nerve 
cell membranes, which plays an important role in supporting neural functions, is PS [64]. PS has been shown to play an important role in the release of acetylcholine, dopamine, and noradrenaline [65]. Many animal studies have provided evidence that PS plays an important role in age-related changes in brain function in aging [66,67]. Oral administration of exogenous PS to aged rats promoted the formation of synapses, dendrites, and surface receptors of nerve cells in different parts of the brain $[66,68]$. Exogenous phosphatidylserine facilitates the normalization of age-related decreases in $\mathrm{Na}^{+} / \mathrm{K}^{+}$-ATPase activity in brain cells [69], optimizes the secretion and reception of several neurotransmitters [70-72], and plays an important role in the control of signal messengers [66]. Alternative pathways for phospholipid synthesis were proposed in different areas of the brain during aging [60]. These pathways include base exchange enzymes, which are calcium-dependent, energy-independent, and calcium-stimulated enzymatic pathways, PE synthesis through phosphatidylserine decarboxylase activity, PC synthesis through the transfer of methyl groups to endogenous PE via phosphatidylethanolamine N-methyl transferase activity, and the synthesis of phosphatidylglycerol (PG) through phospholipase D (PLD) (Figure 3).

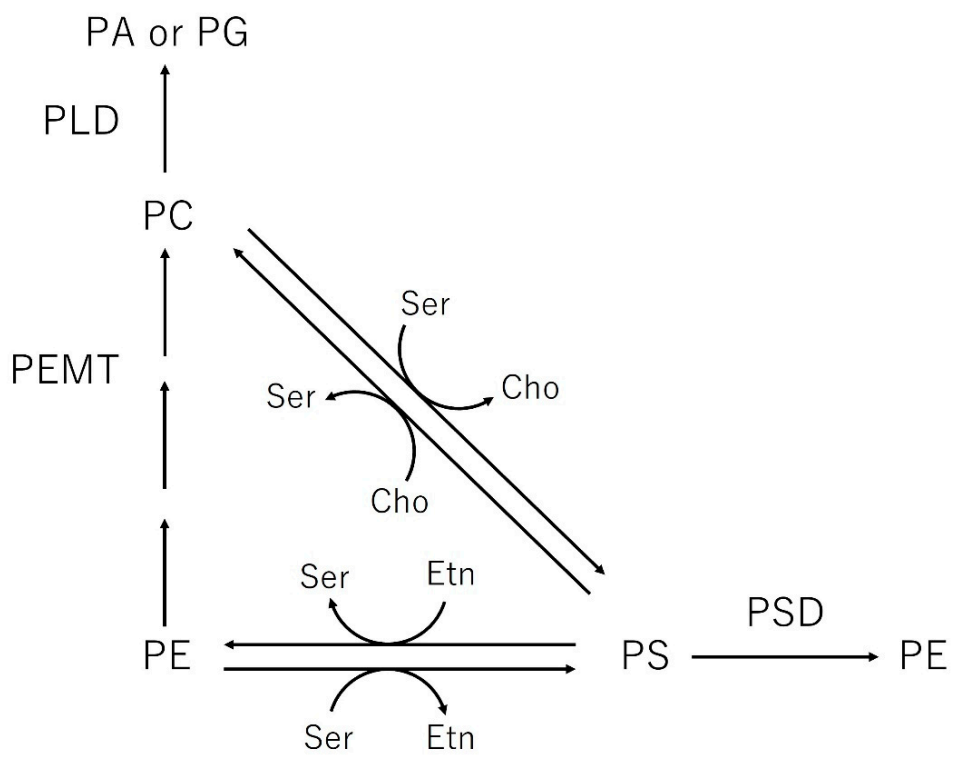

Figure 3. Alternative pathways for phospholipid synthesis in the brain (PA is phosphatidic acid). Ser: serine, Cho: choline, Etn: ethanolamine. Modified from [60] with permission from Elsevier.

Since animal products (eggs, meat, etc.) are the major dietary sources of polar lipids, the relationship between dietary polar lipids and the development of cognitive function has been discussed [73]. In particular, the role of dietary phospholipids in cognitive processes throughout life is considered to be of great importance [74]. Regarding the impact of phospholipids on cognitive development, PC and PS are the most widely studied [74]. The distribution of phospholipids in the brain and the main dietary sources are shown in Table 1.

Table 1. Brain distribution of phospholipids per $\mathrm{mg}$ of tissue and distribution of phospholipids in the main dietary sources expressed as percentage (\%) of total phospholipids. Modified from [74] with permission from Elsevier. Furthermore, a small portion of data from [75] are included.

\begin{tabular}{cccccc}
\hline Samples & PE & PC & PS & PI & SM \\
\hline Brain & $55.2 \%$ & $31.3 \%$ & $8.0 \%$ & $5.3 \%$ & n.d. \\
Milk & $37.5 \%$ & $26 \%$ & $7.2 \%$ & $6.3 \%$ & $23 \%$ \\
Egg yolk & $16.6 \%$ & $76.9 \%$ & n.d. & n.d. & $2.3 \%$ \\
Soybean & $26.2 \%$ & $44 \%$ & n.d. & $14 \%$ & n.d.
\end{tabular}

PC: phosphatidylcholine, PE: phosphatidylethanolamine, PS: phosphatidylserine, PI: phosphatidylinositol, SM: Sphingomyelin. 
Dietary phospholipids were shown to have several health benefits, including improved cognitive function over a lifetime [76,77]. In humans, cognition encompasses and evaluates all biological processes, including attention, learning, memory, reasoning, judgment, decision-making, problem solving, and understanding. In rodents, cognition is primarily assessed by measuring learning, memory, and attention [78].

Many studies have confirmed that supplementation with phospholipids from dairy products can improve cognitive function, which is disrupted by stress and aging (Table 2). The effects of a diet rich in phospholipids on cognitive deficits related to aging have been explored in preclinical studies. One study used a diet supplemented with complex milk lipid concentrate (CMLc) that was rich in phospholipids [79], and another used oral administration of PS isolated from krill or soy [80]. Guan et al. treated 24-month-old rats with gelatin containing CMLc for 4 months [79]. As a result, old rats that orally ingested CMLc showed reduced errors in the probe test in the Morris water maze test. They also reported that compared to the control rats, CMLc-supplemented aged rats showed improved vascular density, dopamine output, and neuroplasticity in the brain regions involved in memory. Lee et al. investigated the effect of oral administration of krill-derived PS ( 20 or $50 \mathrm{mg} / \mathrm{kg}$ body weight/day) and soy-derived PS (50 mg/kg body weight/day) for one week on improving age-related learning and memory impairment in 6-week-old and 12-month-old rats [80]. The escape latency in the Morris water maze was significantly improved in rats fed with krill-derived PS than those fed with soybean-derived PS. Furthermore, in both groups, the age-associated loss of cholinergic immunoreactivity and muscarinic acetylcholine receptor type 1 (mAChR-M1) and choline transporter (CHT) mRNA expression in the hippocampus was significantly alleviated.

Table 2. Supplementation with dairy phospholipids improves disrupted cognition in stress and aging.

\begin{tabular}{|c|c|c|c|}
\hline Compounds & Species & Improved Cognitive Functions & References \\
\hline Complex milk lipids & Rat & Spatial memory & [79] \\
\hline Phosphatidylserine & Human & Learning and verbal memory & [81] \\
\hline Phosphatidylserine & Human & Immediate nonverbal memory & [82] \\
\hline 1,2-dilinoleoyl-sn-glycero-3-phosphocholine & Mouse & Spatial memory & [83] \\
\hline Milk fat globule membrane & Rat & Spatial memory & [84] \\
\hline Bovine milk-derived phospholipid drink & Human & Attention switching & [85] \\
\hline
\end{tabular}

Several human studies on the effects of PS intake on cognitive function were also reported. Previous research showed that PS intake could compensate for cognitive deficits related to old age and $\mathrm{AD}$ in humans $[81,82]$. Cenacchi et al. evaluated the therapeutic efficacy and safety of oral PS versus placebo ( $300 \mathrm{mg} /$ day for 6 months) in 494 elderly patients with cognitive impairment in a double-blind study [81]. The PS group showed significant improvement in both behavioral and cognitive aspects when compared to the placebo group. Engel et al. conducted a double-blind crossover study of phosphatidylserine ( $300 \mathrm{mg}$ / day for 8 weeks) versus placebo in 33 patients with mild primary degenerative dementia (55-75 years old, Mini-Mental State Examination (MMSE) score 15-27) [82]. The results indicated that the PS group showed significant improvement in both behavioral and cognitive aspects when compared to the placebo group. As explained in this section, since phospholipids are essential for brain function, it is clear that their long-term intake from food has a significant impact on cognitive function.

\subsection{Plasmalogens}

Plasmalogen is an alkenyl acyl formed lipid, which has a vinyl ether bond. Half of the brain is lipid, and plasmalogen accounts for approximately $8 \%$ of the brain [86]. Plasmalogen was also reported to prevent neuronal cell death by scavenging singlet oxygen and superoxide anions with its alkenyl (vinyl ether) linkages [87]. The proposed oxidative mechanism of plasmalogen is shown in Figure 4 [88]. 




Figure 4. Proposed oxidative mechanism of plasmalogen. Modified from [88] with permission from The American Society for Biochemistry and Molecular Biology.

Plasmalogen levels were reported to specifically decrease in the postmortem brains of patients with AD [89-91]. Plasmalogen was found to exist in Halocynthia roretzi, and eicosapentaenoic acid (EPA) and docosahexaenoic acid (DHA) are the main compounds [92-94]. Furthermore, ethanolamine plasmalogen, which is present at high levels in the brain, is believed to be involved in neuronal protection. The various food items (food resources derived from cattle, pigs, chickens, and marine products) examined showed a wide range of ethanolamine plasmalogen contents from 5 to $549 \mu \mathrm{mol} / 100 \mathrm{~g}$ wet weight [94]. Marine invertebrates, blue mussels, and ascidians had a high ethanolamine plasmalogen content (over $200 \mu \mathrm{mol} / 100 \mathrm{~g}$ wet weight). The profiling of the molecular species showed that the predominant fatty acids of ethanolamine plasmalogen species were 20:5 (EPA) and 22:6 (DHA) at the $s n-2$ position of the glycerol moiety in marine foodstuffs, whereas the major ethanolamine plasmalogen species in land foodstuffs were 20:4. Following quantitative analysis by multiple reaction monitoring, the viscera of the ascidian contained the highest levels of 18:0/20:5-ethanolamine plasmalogen and 18:0/22:6-ethanolamine plasmalogen ( 86 and $68 \mu \mathrm{mol} / 100 \mathrm{~g}$ wet weight, respectively). To evaluate the neuronal antiapoptotic effect of these ethanolamine plasmalogen species, human neuroblastoma SH-SY5Y cells were treated with PE, purified from the ascidian viscera, under serum starvation conditions. Extrinsic PE from ascidian viscera showed stronger suppression of cell death induced by serum starvation than from bovine brain glycerophospholipids. The glycerophospholipid from ascidian viscera strongly suppressed the activation of caspase 3 . Therefore, ethanolamine plasmalogens, especially those containing EPA and DHA, from marine foodstuffs, are potentially useful as a therapeutic dietary supplement to prevent neurodegenerative diseases such as AD. Moreover, it was found that plasmalogen, which originates in sea squirt, is an anti-apoptosis factor in nerve cells and the administration of plasmalogen improves long and short-term dementia [33]. One article also reported a significant improvement in cognitive function and clinical symptoms such as $\mathrm{AD}$ and $\mathrm{PD}$ with the elevation of blood plasmalogen levels [95]. Although these findings suggest that plasmalogen has important physiological functions, its absorption and metabolism are not fully understood, mainly due to the lack of plasmalogen resources [96,97]. 


\section{3. $\omega 3$. Fatty Acids}

Long-chain $\omega 3$ fatty acids, such as EPA and DHA, are important for brain function and mental health [98-100], and several studies showed an association between $\omega 3$ fatty acids and cognitive performance (Table 3 ).

Table 3. Previous study on the relationship between $\omega 3$ fatty acids and cognitive function.

\begin{tabular}{|c|c|c|}
\hline Study Samples & Results & References \\
\hline $\begin{array}{l}\text { Blood plasma of AD patients, patients of dementia and } \\
\text { patients who are cognitively impaired but nondemented }\end{array}$ & $\begin{array}{l}\text { Low levels of } \omega 3 \text { fatty acids in the plasma may be } \\
\text { a risk factor for cognitive impairment and/or } \\
\text { dementia. }\end{array}$ & [101] \\
\hline $\begin{array}{l}\text { Data from cross-sectional population-based study among } \\
\text { subjects aged } 45-70 \text { years }\end{array}$ & $\begin{array}{l}\text { Fatty fish and marine } \omega 3 \text { PUFA consumption was } \\
\text { associated with a reduced risk and intake of } \\
\text { cholesterol and saturated fat with an increased risk } \\
\text { of impaired cognitive function in the middle-aged } \\
\text { population. }\end{array}$ & [102] \\
\hline $\begin{array}{l}\text { Erythrocyte membrane of men and women (aged } \\
\text { 63-74 years) from the Etude du Vieillissement Artériel } \\
\text { (EVA) cohort }\end{array}$ & $\begin{array}{l}\text { The inverse association between cognitive decline } \\
\text { and the ratio of } \omega 3 \text { to } \omega 6 \text { fatty acid in erythrocyte } \\
\text { membranes was confirmed. }\end{array}$ & [103] \\
\hline $\begin{array}{l}\text { Data derived from a cohort of men, aged } 69-89 \text { years, who } \\
\text { were participants in the Zutphen Elderly Study }\end{array}$ & $\begin{array}{c}\text { High linoleic acid intake was positively associated } \\
\text { with cognitive impairment and high fish } \\
\text { consumption inversely associated with cognitive } \\
\text { impairment. }\end{array}$ & [104] \\
\hline Plasma of men and women aged $50-70$ years & $\begin{array}{c}\text { Promoting higher intakes of } \omega 3 \text { PUFA in the diet } \\
\text { of hypertensive and dyslipidemic people may have } \\
\text { substantial benefits in terms of reducing their risk } \\
\text { of cognitive decline in the area of verbal fluency. } \\
\text { Plasma } \omega 3 \text { PUFA proportions were associated } \\
\text { with less decline in the speed-related cognitive } \\
\text { domains over } 3 \text { years. }\end{array}$ & [106] \\
\hline
\end{tabular}

Therefore, the consumption of fish as food can contribute to the improvement of cognitive function [107-111]. A large study conducted under the National Health and Nutrition Examination Survey (NHANES) in 2011-2014 reported an association between dietary intake of $\omega 3$ and $\omega 6$ fatty acids and cognitive function in the elderly. A total of 2496 participants aged 60 years and older were included in the study [112-114]. The NHANES study reported the following results: in the fully adjusted model, the odds ratios and $95 \%$ confidence intervals for the Consortium to Establish a Registry for Alzheimer's Disease (CERAD) test score, Animal Fluency test score, and DANTES Subject Standardized Test (DSST) score were 0.58 (0.38-0.88), 0.68 (0.47-0.99), and 0.59 (0.37-0.99), respectively, for the upper to lower quartiles of $\omega 3$ fatty acid intake. Meanwhile, the odds ratios and 95\% confidence intervals for the CERAD test score, Animal Fluency test score, and DSST test score were $0.48(0.31-0.75), 0.60(0.40-0.92)$, and $0.590(0.34-0.75)$ for the upper to lower quartiles of $\omega 6$ fatty acid intake, respectively. The association between the $\omega 6: \omega 3$ ratio and cognitive performance was not statistically significant in the three tests. In the dose-response relationship analysis, L-shaped associations were apparent for $\omega 3$ and $\omega 6$ fatty acid intake in relation to the CERAD test score, animal fluency test score, and DSST test score. Therefore, dietary $\omega 3$ and $\omega 6$ fatty acid intake may be inversely associated with low cognitive performance. Previous reports on the effects of dietary $\omega 3$ and $\omega 6$ fatty acids on cognitive decline yielded contradictory results, making it difficult to conclude its usefulness at this time. Further studies will clarify the relationship between $\omega 3$ and $\omega 6$ fatty acid intake and cognitive function in the future.

\subsection{Cholesterols}

The relationship between cholesterol and cognitive function has not yet been definitively determined; however, there have been several studies. Earlier results suggested a link between high midlife cholesterol levels and increased risk of dementia [115-118], 
while later studies did not find an association between midlife cholesterol and subsequent dementia [119-122]. Furthermore, studies on late-life cholesterol levels contradicted some studies reporting that low late-life cholesterol was associated with an increased risk of dementia, although others did not find an association [123-125]. In a recent study, the relationship between cholesterol levels and cognitive function depended on homocysteine levels, suggesting an interactive role between cholesterol and homocysteine in cognitive function in the elderly population [126]. Moreover, it has also been reported that the consumption of arachidonic acid and cholesterol through dietary fat intake may be associated with an increased risk of PD [127]. Furthermore, niacin, which increases high-density protein [128], could play a key role in the improvement of PD because one study has shown an association between high-density lipoprotein cholesterol variability and a risk of developing PD [129].

\subsection{Carotenoids}

Carotenoids have all trans-type conjugated double bonds and are considered to be antioxidants and important compounds in the longevity of primate species $[130,131]$. Therefore, the carotenoid supply of food reduces oxygen stress and contributes to the aging epidemic disease by increasing its concentration in the body. The rate of electron transfer from the carotenoid radical anion to oxygen was previously studied [132]. The hypothesis that carotenoids play a preventive role in cognitive impairment is suggested by their ability to trap peroxyl radicals and their singlet oxygen-quenching properties, allowing them to prevent lipid peroxidation $[132,133]$. Epidemiological studies and clinical trials on cognitive impairment and plasma carotenoids are mainly concerned with $\beta$-carotene, which is a major carotenoid [134-140]. On the other hand, several studies showed that the antioxidant activity of other carotenoids could be more effective than $\beta$-carotene activity $[141,142]$. Specifically, the role of lutein in cognitive function throughout life is important [143], and a possible role of lutein in cognitive function in the elderly was reported [144]. In this study, 49 women (age, $60-80$ years) were randomly assigned to receive DHA $(800 \mathrm{mg} / \mathrm{d} ; \mathrm{n}=14)$, lutein $(12 \mathrm{mg} / \mathrm{d} ; \mathrm{n}=11)$, a combination of DHA and lutein $(\mathrm{n}=14)$, or placebo $(\mathrm{n}=10)$. Participants underwent cognitive tests measuring verbal fluency, memory, processing speed, and accuracy and provided self-reports of mood at randomization and at the end of the trial. After supplementation, verbal fluency scores improved significantly in the combined treatment group, and individuals in this group also showed a trend toward more efficient learning. Measures of mental processing speed, accuracy, and mood were not affected by supplementation. Therefore, this study suggests that DHA and lutein improve cognitive function in older adults. Among erythrocyte antioxidants, xanthophyll lutein in $\mathrm{AD}$ was lower than in healthy participants, and lutein tended to decrease as the level of $\mathrm{AD}$ increased [35]. It was also reported that amyloid $\beta$ induces oxidative injury to erythrocytes by binding to them, causing phospholipid peroxidation and diminishing xanthophylls and lutein [145]. A similar trend to that of lutein was reported with astaxanthin (a carotenoid that was reported to exhibit stronger antioxidant activity in vitro than lutein) [146]. In addition, the possibility of lutein supply through the ingestion of Chlorella pyrenoidosa was suggested because it includes lutein in abundance [147,148], and it has been reported that its dietary intake increases lutein concentration in blood [149].

\subsection{Vitamins}

Vitamin and antioxidant enzymes play a fundamental role in protecting the organism from oxidative stress, which is associated with longevity [150]. The major natural antioxidant vitamins, most of which are derived from natural sources by dietary intake, are vitamin C, vitamin E, and vitamin A [150]. The link between vitamin C status and cognitive performance in cognitively intact and impaired individuals (including AD and dementia) was evaluated [151]. Some studies showed a significantly lower vitamin C blood concentration in cognitively impaired individuals than in healthy individuals [152-154]. Furthermore, vitamin E, particularly $\alpha$-tocopherol, is the major chain-breaking antioxidant 
in plasma [155] and cell membranes [156]. The function of vitamin $\mathrm{E}$ as a regulatory redox interaction was reported [157]. A link between vitamin E and aging, dementia, and AD was suggested because of its antioxidant function [158]. Furthermore, the importance of vitamin A in brain function, behavior, and learning was argued [159]. In light of the recent attention given to the effects of micronutrients on human cognition, it is surprising that vitamin A received relatively little attention compared to other vitamins $[160,161]$. Vitamin A and its derivatives, which are essential for human health, modulate several physiological processes through their interactions with the nuclear retinoic acid receptors (RARs) and retinoid X receptors (RXRs) [162]. High levels of vitamins A and E appear to be important in guaranteeing extreme longevity [150]. Plasma levels of ascorbic acid, uric acid, $\alpha$-tocopherol, retinol, carotenoids, total thiol groups, and the activity of plasma superoxide dismutase (SOD) and glutathione peroxidase (GPX), as well as the activity of red blood cell (RBC) SOD, were measured. Participants were divided into the following four groups according to age: 32 healthy centenarians, 17 elderly participants aged 80-99 years, 34 elderly participants aged 60-79 years, and 24 adults aged less than 60 years. Considering only the non-centenarians, consistent behavior in the antioxidant pattern, with a decrease in non-enzymatic antioxidants and an increase in enzymatic antioxidant activity relative to age, was observed. Remarkably, centenarians were characterized as having the highest levels of retinol and $\alpha$-tocopherol, whereas the activities of plasma and RBC SOD, which increased with age, decreased in centenarians. From these results, healthy centenarians showed a particular profile in which high levels of retinol and $\alpha$-tocopherol seemed to be important to guarantee their extreme longevity. However, a later study reported different antioxidant profiles of vitamin A and E in Italian centenarians [163]. Furthermore, the roles of vitamins B, D, and K in aging adults were also reported [164-168]. For example, apolipoprotein $\mathrm{E}(\mathrm{APOE}) \varepsilon 4$ is a genetic predisposing factor that modulates the effect of vitamin B-12 on cognitive function [164]. Neuropsychological tests, including the MMSE for global cognition, were administered at the baseline assessment to 539 Chinese adults ( $\geq 55$ years). MMSE was repeated at a median of 18 months $(n=376)$ and 38 months $(n=247)$ after baseline. The interaction of vitamin B-12 and APOE $\varepsilon 4$ with cognitive function was examined using a linear mixed effects model for MMSE and a multiple linear regression model for neuropsychological test scores. As a result, APOE $\varepsilon 4$ was associated with a lower MMSE score. Vitamin B-12 was positively related to the MMSE score, and this association was much stronger in APOE $\varepsilon 4$ carriers than in APOE $\varepsilon 4$ noncarriers. Significant interactions between natural log-transformed vitamin B-12 and APOE $\varepsilon 4$ were also found for the digit span backward longest sequence, and for immediate recall in the Rey auditory verbal learning test. Better performance in these two tests was associated with vitamin B-12 in APOE $\varepsilon 4$ carriers but not in APOE $\varepsilon 4$ noncarriers. Therefore, the association between vitamin B-12 and cognitive function was moderated by APOE $\varepsilon 4$ status. In addition, the effect of low vitamin D on cognition and the relationship between vitamin D and PD were reported [167,169].

\subsection{Phenolic Compounds}

The use of potent antioxidant nutritional substances, such as (poly)phenols, was proposed in the study of age-related cognitive disorders [170-172]. The effects of the consumption of flavonoids and other polyphenols on cognitive performance were discussed, and the findings of previous human experimental and epidemiological studies imply that the consumption of polyphenols has the potential to benefit cognition both acutely and chronically [173]. Recent data from randomized placebo-controlled trials suggest that (poly)phenols may also modulate neurological disorders, cerebral hypoperfusion, and neuroinflammation while simultaneously improving memory, learning, and cognitive performance in older adults (Table 4) [170,174-182]. 
Table 4. Improvement of functions in older adults by daily intake of polyphenols.

\begin{tabular}{|c|c|c|}
\hline Dietaries & Improved Functions & References \\
\hline Cocoa with flavanol & Cognitive function, blood pressure control and metabolic profile & [174] \\
\hline Blueberry & Episodic memory performance and cardiovascular disease & [175] \\
\hline Greek mountain tea & Cognitive function & [176] \\
\hline Dietary with resveratrol & $\begin{array}{c}\text { Memory performance in association with improved glucose metabolism } \\
\text { and increased hippocampal functional conectivity }\end{array}$ & [177] \\
\hline Cocoa with flavanol & Regional cerebral perfusion & [178] \\
\hline Blueberry & $\begin{array}{l}\text { Brain perfusion and activation in brain areas associated with } \\
\text { cognitive function }\end{array}$ & [179] \\
\hline Fruit and $100 \%$ fruit juice & $\begin{array}{c}\text { Cardiovascular disease, memory/cognition, obesity/diabetes and } \\
\text { exercise performance }\end{array}$ & [180] \\
\hline Soy with isoflavone & Cognitive function & [181] \\
\hline Dietary with flavonol & Developing Alzheimer dementia & [182] \\
\hline
\end{tabular}

However, other studies reported nonsignificant effects or even unwanted effects of (poly)phenol-rich supplementation on certain cognitive functions, specifically executive functioning, working memory, and verbal memory $[183,184]$, or the response of cerebral blood flow, and are thus controversial [185]. Among various polyphenolic compounds, curcumin is considered a promising therapeutic agent for altering the cognitive symptoms of $\mathrm{AD}$, and several preclinical studies were conducted to verify its efficacy $[186,187]$. One of the main reasons for this is that it was reported to bind to amyloid $\beta$ plaques, decrease neurotoxicity, and initiate their degradation. However, only a limited number of clinical studies examined the effects of curcumin on human cognitive functioning. Some studies did not report cognitive-enhancing effects of curcumin $[188,189]$, while other studies suggested a beneficial effect of curcumin on cognition $[190,191]$. Some studies suggest that curcumin is responsible for mechanisms that are protective against cognitive decline $[188,191]$. The results concerning the reduction in amyloid $\beta$ are ambiguous since most of the peripheral measurements, such as plasma, serum, and CSF (Chalder Fatigue Scale) levels, did not detect significant changes in amyloid $\beta$ or tau levels between curcumin and placebo [188,192]; however, neuroimaging supports that curcumin reduces amyloid $\beta$ deposits in the brain [192]. Most orally administered curcumin undergoes glucuronidation and sulfate conjugation during Phase 1 and Phase 2 metabolism in the liver and small intestine before entering the bloodstream $[193,194]$. Since the physiological and antioxidant effects of curcumin are known to decrease after undergoing metabolism (conjugation), it will be necessary to evaluate curcumin and cognitive function while taking metabolism into account in the future $[195,196]$.

\subsection{Amino acids, Peptides, and Proteins}

As introduced in the previous chapter, amyloid $\beta$ was suggested to play an important role in the development and progression of AD. The elucidation of the pathological mechanisms of amyloid $\beta 42$ in AD attracted interest in relation to the discovery of new drugs [197]. Therefore, the role of peptides in cognitive function is important. In addition to long-form peptides, small oligopeptides are also very important compounds in cognitive function. For example, it was hypothesized that lactotripeptide ingestion increases cerebral blood flow and cognitive function [198]. Age-related decreases in cerebral blood flow velocity increase the risk of cerebrovascular disease. Bioactive peptides derived from milk proteins, such as lactotripeptide, were shown to inhibit angiotensin-converting enzyme (ACE) activity and increase vasodilator production. ACE is a central component of the renin-angiotensin system, which controls blood pressure by regulating the volume of fluid in the body and converts the hormone angiotensin I to the active vasoconstrictor angiotensin II. Valine-proline-proline (VPP) and isoleucine-proline-proline (IPP) exist in lactotripeptides. Furthermore, Met-Lys-Pro (MKP), a casein-derived ACE inhibitory peptide with the potential to cross the blood-brain barrier, was also reported to attenuate cognitive decline in a mouse model of AD [199]. Milk peptide (casein hydrolysate (CH)-3), 
which contains MKP and adult male ddY mice, was used in this study. An animal model of $\mathrm{AD}$ was induced by intracerebroventricular (ICV) injection of amyloid $\beta 1-42$. CH-3 $(250 \mathrm{mg} / \mathrm{kg} /$ day) or MKP $(0.5 \mathrm{mg} / \mathrm{kg} /$ day $)$ was administered orally every day from 2 days before ICV injection. Three weeks after ICV injection, cognitive function was evaluated using the Morris water maze test. Daily administration of $\mathrm{CH}-3$ markedly attenuated amyloid $\beta$ 1-42-induced cognitive decline. The effects of MKP on human cognition were also investigated [200]. Furthermore, imidazole-containing amino acids and dipeptides are known as antioxidants in general [201,202]; carnosine in the histidine metabolism pathway has been reported to decrease in AD plasma [203]. Moreover, glutathione is also known as an antioxidant for the cellular detoxification of ROS in the brain $[45,204]$. Recently, Ozawa et al. developed a method for the comprehensive analysis of dipeptides and showed that the profiles of dipeptides in the body were greatly altered in diseases such as cancer $[205,206]$. Clarifying the dynamics of dipeptides in food and the body will be important to elucidate the mechanism of cognitive decline. Meanwhile, protein/amino acid intake is a growing area of research related to the prevention of $A D$ and related dementia [207], and consumption is directly related to a number of disease-related risk factors such as low muscle mass, poor sleep, stress, depression, and anxiety. As a result, the role of protein/amino acid intake in terms of affecting modifiable risk factors for cognitive decline has provided a robust area for scientific exploration. However, this research is still speculative and specific mechanisms have to be proven.

\subsection{Others}

In other studies, dietary boron, brain function, and cognitive performance were reported [208]. Penland evaluated the relationship between brain electrophysiological responses to boron intake (about $0.25 \mathrm{mg}$ boron $/ 2000 \mathrm{kcal} /$ day and approximately $3.25 \mathrm{mg}$ boron $/ 2000 \mathrm{kcal} /$ day) and cognitive performance in healthy elderly men and women (65 people in total). They reported that performance was significantly lower in manual dexterity, eye-hand coordination, attention, perception, encoding, and short-term memory and long-term memory tests when boron intake was low as opposed to when boron intake was high. The effect of dietary nitrate on cognitive function in the elderly has been the subject of some debate, although no definite effect has been reported $[209,210]$. In these reports, dietary nitrate supplementation reduced resting blood pressure and improved $\mathrm{O}_{2}$ uptake kinetics during treadmill walking in healthy older adults, but did not improve walking or cognitive performance. Therefore, nitrate supplementation was shown to improve exercise performance and cardiovascular response, but its benefits on cognitive performance are unclear. Moreover, there is a discussion about whether caffeine is a cognitive enhancer [211,212]. Over 26 years, up to 2000, global coffee consumption increased by $67.9 \%$. Therefore, elucidation of the relationship between cognitive function and caffeine will be of increasing interest [213].

\section{Conclusions}

In this review, the effects of various food components on cognitive function are presented based on previous reports. Dementia is an important problem in a modern aging society. Based on the research presented in this review, a proper diet that preserves cognitive function could improve age-related cognitive decline, AD, and PD. As mentioned in this review, there are many types of functional components in food. However, there is no direct evidence that any food component improves cognitive function, and the effect of food components on cognitive function remains unclear. An understanding of foods composed of various components will be necessary for future research on cognitive functions. Reactive oxidative species are deeply associated with aging, and biomolecules are oxidatively damaged according to the "free radical theory". Hence, the function of food compounds as antioxidants is expected to improve age-related disorders. Food compounds that have these functions are included in daily meals. Therefore, maintaining dietary habits is important to maintaining health in old age. New quantitative methods have been 
developed for compounds related to cognitive functions (lipid peroxidation, dipeptides, etc.) that have been difficult to analyze in the past. These methods of analyzing foods and the human body will contribute to the discovery of new functions of foods to improve dementia in an aging society. Hopefully, this review will help to trigger the development of new foods and technologies that improve aging and cognitive functions and extend the healthy life span.

Author Contributions: Conceptualization, H.O., T.M. (Taiki Miyazawa) and T.M. (Teruo Miyazawa); writing — original draft preparation, H.O.; writing—review and editing, H.O., T.M. (Taiki Miyazawa) and T.M. (Teruo Miyazawa); visualization, H.O.; supervision, T.M. (Taiki Miyazawa) and T.M. (Teruo Miyazawa). All authors have read and agreed to the published version of the manuscript.

Funding: This work was supported by the Tohoku University Fund.

Conflicts of Interest: The authors declare no conflict of interest.

\section{References}

1. United Nations, Department of Economic and Social Affairs, Population Division. World Population Ageing 2017—Highlights (ST/ESA/SER.A /408). Available online: http://www.un.org/en/development/desa/population/publications/pdf/ageing/ WPA2017_Highlights.pdf (accessed on 28 September 2018).

2. Cahill, S. WHO's global action plan on the public health response to dementia: Some challenges and opportunities. Aging Ment. Health 2020, 24, 197-199. [CrossRef] [PubMed]

3. Blazer, D.G.; Yaffe, K.; Karlawish, J. Cognitive aging: A report from the institute of medicine. J. Am. Med. Assoc. 2015, 313, 2121-2122. [CrossRef] [PubMed]

4. Luppa, M.; Luck, T.; Weyerer, S.; König, H.-H.; Brähler, E.; Riedel-Heller, S.G. Prediction of institutionalization in the elderly. A systematic review. Age Ageing 2010, 39, 31-38. [CrossRef]

5. Winblad, B.; Amouyel, P.; Andrieu, S.; Ballard, C.; Brayne, C.; Brodaty, H.; Cedazo-Minguez, A.; Dubois, B.; Edvardsson, D.; Feldman, H.; et al. Defeating Alzheimer's disease and other dementias: A priority for European science and society. Lancet Neurol. 2016, 15, 455-532. [CrossRef]

6. van de Rest, O.; Berendsen, A.A.M.; Haveman-Nies, A.; CPGM de Groot, L. Dietary patterns, cognitive decline, and dementia: A systematic review. Adv. Nutr. 2015, 6, 154-168. [CrossRef]

7. Erro, R.; Brigo, F.; Tamburin, S.; Zamboni, M.; Antonini, A.; Tinazzi, M. Nutritional habits, risk, and progression of Parkinson disease. J. Neurol. 2018, 265, 12-23. [CrossRef] [PubMed]

8. Mumme, K.D.; von Hurst, P.R.; Conlon, C.A.; Jones, B.; Haskell-Ramsay, C.F.; Stonehouse, W.; Heath, A.-L.M.; Coad, J.; Beck, K.L. Study protocol: Associations between dietary patterns, cognitive function and metabolic syndrome in older adults-A cross-sectional study. BMC Public Health 2019, 19, 535. [CrossRef] [PubMed]

9. Aridi, Y.S.; Walker, J.L.; Wright, O.R.L. The association between the Mediterranean dietary pattern and cognitive health: A systematic review. Nutrients 2017, 9, 674. [CrossRef] [PubMed]

10. Taylor, V.H.; MacQueen, G.M. Cognitive dysfunction associated with metabolic syndrome. Obes. Rev. 2007, 8, 409-418. [CrossRef]

11. Guicciardi, M.; Crisafulli, A.; Doneddu, A.; Fadda, D.; Lecis, R. Effects of metabolic syndrome on cognitive performance of adults during exercise. Front. Physiol. 2019, 10, 1845. [CrossRef]

12. Chen, J.J.; Yu, B.P. Alterations in mitochondrial membrane fluidity by lipid peroxidation products. Free Radic. Biol. Med. 1994, 17, 411-418. [CrossRef]

13. Sohal, R.S.; Agarwal, S.; Sohal, B.H. Oxidative stress and aging in the Mongolian gerbil (Meriones unguiculatus). Mech. Ageing Dev. 1995, 81, 15-25. [CrossRef]

14. Roger, T.D.; Shanlin, F.U.; Roland, S.; Michael, J.D. Biochemistry and pathology of radical-mediated protein oxidation. Biochem. J. 1997, 324, 1-18.

15. Mecocci, P.; Fanó, G.; Fulle, S.; MacGarvey, U.; Shinobu, L.; Polidori, M.C.; Cherubini, A.; Vecchiet, J.; Senin, U.; Beal, M.F. Age-dependent increases in oxidative damage to DNA, lipids and proteins in human skeletal muscle. Free Radic. Biol. Med. 1999, 26, 303-308. [CrossRef]

16. Mecocci, P.; MacGarvey, U.; Kaufman, A.E.; Koontz, D.; Shoffner, J.M.; Wallace, D.C.; Beal, M.F. Oxidative damage to mitochondrial DNA shows marked age-dependent increases in human brain. Ann. Neurol. 1993, 34, 609-616. [CrossRef] [PubMed]

17. Wei, Y.-H.; Kao, S.-H.; Lee, H.-C. Simultaneous increase of mitochondrial DNA deletions and lipid peroxidation in human aging. Ann. N. Y. Acad. Sci. 1996, 786, 24-43. [CrossRef]

18. Harman, D. Aging: A theory based on free radical and radiation chemistry. J. Gerontol. 1956, 11, 298-300. [CrossRef]

19. Beckman, K.; Ames, B.N. The free radical theory of aging matures. Physiol. Rev. 1998, 78, 547-581. [CrossRef]

20. Gülçin, İ. Antioxidant activity of food constituents: An overview. Arch. Toxicol. 2012, 86, 345-391. [CrossRef] [PubMed]

21. Patel, R.P.; McAndrew, J.; Sellak, H.; White, C.R.; Jo, H.; Freeman, B.A.; Darley-Usmar, V.M. Biological aspects of reactive nitrogen species. Biochem. Biophys. Acta 1999, 1411, 385-400. [CrossRef] 
22. Drew, B.; Leeuwenburgh, C. Aging and the role of reactive nitrogen species. Ann. N. Y. Acad. Sci. 2002, 959, 66-81. [CrossRef] [PubMed]

23. Annunziato, L.; Pannaccione, A.; Cataldi, M.; Secondo, A.; Castaldo, P.; Renzo, G.D.; Taglialatela, M. Modulation of ion channels by reactive oxygen and nitrogen species: A pathophysiological role in brain aging? Neurobiol. Aging 2002, 23, 819-834. [CrossRef]

24. Miyazawa, T. Lipid hydroperoxides in nutrition, health, and diseases. Proc. Jpn. Acad. Ser. B 2021, 97, 161-196. [CrossRef]

25. Miyazawa, T.; Yasuda, K.; Fujimoto, K.; Kaneda, T. Presence of phosphatidylcholine hydroperoxide in human plasma. J. Biochem. 1988, 103, 744-746. [CrossRef]

26. Mohanty, J.G.; Eckley, D.M.; Williamson, J.D.; Launer, L.J.; Rifkind, J.M. Do red blood cell- $\beta$-amyloid interactions alter oxygen delivery in Alzheimer's disease? Adv. Exp. Med. Biol. 2008, 614, 29-35. [PubMed]

27. Skoumalová, A.; Ivica, J.; Šantorová, P.; Topinková, E.; Wilhelm, J. The lipid peroxidation products as possible markers of Alzheimer's disease in blood. Exp. Gerontol. 2011, 46, 38-42. [CrossRef] [PubMed]

28. Baldeiras, I.; Isabel, S.; Teresa, P.M.; Helena, G.M.; Rui, P.; Ana, R.; Diana, D.; Resende, O.C. Peripheral oxidative damage in mild cognitive impairment and mild Alzheimer's disease. J. Alzheimer's Dis. 2008, 15, 117-128. [CrossRef]

29. Bermejo, P.; Martín-Aragón, S.; Benedí, J.; Susín, C.; Felici, E.; Gil, P.; Ribera, J.M.; Villar, A.M. Peripheral levels of glutathione and protein oxidation as makers in the development of Alzheimer's disease from mild cognitive impairment. Free Radic. Res. 2008, 42, 162-170. [CrossRef]

30. Chang, C.-Y.; Liang, H.-J.; Chow, S.-Y.; Chen, S.-M.; Liu, D.-Z. Hemorheological mechanisms in Alzheimer's disease. Microcirculation 2007, 14, 627-634. [CrossRef]

31. Kawamoto, E.M.; Munhoz, C.D.; Glezer, I.; Bahia, V.S.; Caramelli, P.; Nitrini, R.; Gorjāo, R.; Curi, R.; Scavone, C.; Marcourakis, T. Oxidative state in platelets and erythrocytes in aging and Alzheimer's disease. Neurobiol. Aging 2005, 26, 857-864. [CrossRef]

32. Nakagawa, K.; Kiko, T.; Kuriwada, S.; Miyazawa, T.; Kimura, F.; Miyazawa, T. Amyloid $\beta$ induces adhesion of erythrocytes to endothelial cells and affects endothelial viability and functionality. Biosci. Biotehonol. Biochem. 2011, 75, 2030-2033. [CrossRef]

33. Yamashita, S.; Kiko, T.; Fujiwara, H.; Hashimoto, M.; Nakagawa, K.; Kinoshita, M.; Furukawa, K.; Arai, H.; Miyazawa, T. Alterations in the levels of Amyloid- $\beta$, phospholipid hydroperoxide, and plasmalogen in the blood of patients with Alzheimer's disease: Possible interactions between amyloid- $\beta$ and these lipids. J. Alzheimer's Dis. 2016, 50, 527-537. [CrossRef] [PubMed]

34. Miyazawa, T.; Suzuki, T.; Yasuda, K.; Fujimoto, K.; Meguro, K.; Sasaki, H. Accumulation of phospholipid hydroperoxides in red blood cell membranes in Alzheimer disease. In Oxygen Radicals; Elsevier Science Publisher: Amsterdam, The Netherlands, 1992; pp. 327-330.

35. Kiko, T.; Nakagawa, K.; Tsuduki, T.; Suzuki, T.; Arai, H.; Miyazawa, T. Significance of lutein in red blood cells of Alzheimer's disease patients. J. Alzheimer's Dis. 2011, 28, 593-600. [CrossRef]

36. Miyazawa, T. Determination of phospholipid hydroperoxides in human blood plasma by a chemiluminescence-HPLC assay. Free Rad. Biol. Med. 1989, 7, 209-218. [CrossRef]

37. Miyazawa, T.; Yasuda, K.; Fujimoto, K. Chemiluminescence-high performance liquid chromatography of phosphatidylcholine hydroperoxide. Anal. Lett. 1987, 20, 915-925. [CrossRef]

38. Seitz, W.R. Chemiluminescence detection of enzymatically generated peroxide. In Bioluminescence and Chemiluminescence; Academic press: New York, NY, USA, 1978; pp. 445-462.

39. Hoshino, H.; Hinze, W.L. Exploitation of reversed micelles as a medium in analytical chemiluminescence measurements with application to the determination of hydrogen peroxide using luminol. Anal. Chem. 1987, 50, 496-504. [CrossRef]

40. Miyazawa, T.; Fujimoto, K.; Kaneda, T. Detection of picomole levels in lipid hydroperoxides by a chemiluminescence assay. Agric. Biol. Chem. 1987, 51, 2569-2573.

41. White, E.H.; Bursey, M.M. Chemiluminescence of luminol and related hydrazides: The light emission step. J. Am. Chem. Soc. 1964, 86, 941-942. [CrossRef]

42. Yue, L.; Liu, Y.-J. Two conical intersections control luminol chemiluminescence. J. Chem. Theory Comput. 2019, 15, 1798-1805. [CrossRef] [PubMed]

43. Miyazawa, T.; Nakagawa, K.; Takekoshi, H.; Higuchi, O.; Kato, S.; Kondo, M.; Kimura, F.; Miyazawa, T. Ingestion of chlorella reduced the oxidation of erythrocyte membrane lipids in senior Japanese subjects. J. Oleo Sci. 2013, 62, 873-881. [CrossRef]

44. Burdeos, G.C.; Nakagawa, K.; Kimura, F.; Miyazawa, T. Tocotrienol attenuates triglyceride accumulation in HepG2 cells and F344 rats. Lipids 2012, 47, 471-481. [CrossRef]

45. Vitalakumar, D.; Sharma, A.; Flora, S.J.S. Ferroptosis: A potential therapeutic target for neurodegenerative diseases. J. Biochem. Mol. Toxicol. 2021, e22830.

46. Langelier, B.; Linard, A.; Bordat, C.; Lavialle, M.; Heberde, C. Long chain-polyunsaturated fatty acids modulate membrane phospholipid composition and protein localization in lipid rafts of neural stem cell cultures. J. Cell Biochem. 2010, 110, 1356-1364. [CrossRef]

47. Castro-Gómez, P.; Garcia-Serrano, A.; Visioli, F.; Fontecha, J. Relevance of dietary glycerophospholipids and sphingolipids to human health. Prostaglandins Leukot. Essent. Fatty Acids 2015, 101, 41-51. [CrossRef]

48. Wehrmüller, K. Impact of dietary phospholipids on human health. APL Sci. 2008, 524, 1-15.

49. Arouri, A.; Mouritsen, O.G. Membrane-perturbing effect of fatty acids and lysolipids. Prog. Lipid Res. 2013, 52, 130-140. [CrossRef] 
50. Chang, H.-C.; Chang, C.-D.; Chen, P.-H.; Chang, C.-J.; Liu, S.-H.; Chen, C.-C. Docosahexaenoic acid and phosphatidylserine improves the antioxidant activities in vitro and in vivo and cognitive functions of the developing brain. Food Chem. 2013, 138, 342-347. [CrossRef] [PubMed]

51. Meck, W.H.; Williams, C.L. Choline supplementation during prenatal development reduces proactive interference in spatial memory. Dev. Brain Res. 1999, 118, 51-59. [CrossRef]

52. Cheatham, C.L.; Goldman, B.D.; Fischer, L.M.; da Costa, K.-M.; Reznick, J.S.; Zeisel, S.H. Phosphatidylcholine supplementation in pregnant women consuming moderate-choline diets does not enhance infant cognitive function: A randomized, double-blind, placebo-controlled trial. Am. J. Clin. Nutr. 2012, 96, 1465-1472. [CrossRef]

53. Ross, R.G.; Hunter, S.K.; Hoffman, C.; McCarthy, L.; Chambers, B.M.; Law, A.J.; Leonard, S.; Zerbe, G.O.; Freedman, R. Perinatal phosphatidylcholine supplementation and early childhood behavior problems evidence for CHRNA7 moderation. Am. J. Psychiatry 2015, 173, 509-516. [CrossRef] [PubMed]

54. Koval, M.; Pagano, R.E. Intracellular transport and metabolism of sphingomyelin. Biochim. Biophys. Acta 1991, 1082, 113-125. [CrossRef]

55. Cutler, R.G.; Mattson, M.P. Sphingomyelin and ceramide as regulators of development and lifespan. Mech. Ageing Dev. 2001, 122, 895-908. [CrossRef]

56. Don, A.S.; Hsiao, J.-H.T.; Bleasel, J.M.; Couttas, T.A.; Halliday, G.M.; Kim, W.S. Altered lipid levels provide evidence for myelin dysfunction in multiple system atrophy. Acta Neuropathol. Commun. 2014, 2, 150. [CrossRef]

57. Ledesma, M.D.; Brügger, B.; Bünning, C.; Wieland, F.T.; Dotti, C.G. Maturation of the axonal plasma membrane requires upregulation of sphingomyelin synthesis and formation of protein-lipid complexes. EMBO J. 1999, 18, 1761-1771. [CrossRef]

58. Bienias, K.; Fiedorowicz, A.; Sadowska, A.; Prokopiuk, S.; Car, H. Regulation of sphingomyelin metabolism. Pharmacol. Rep. 2016, 68, 570-581. [CrossRef]

59. Giusto, N.M.; Roque, M.E.; Ilincheta de Boschero, M.G. Effects of aging on the content, composition and synthesis of sphingomyelin in the central nervous system. Lipids 1992, 27, 835-839. [CrossRef]

60. Ilincheta de Boschero, M.G.; Roque, M.E.; Giusto, N.M. Alternative pathways for phospholipid synthesis in different brain areas during aging. Exp. Gero. 2000, 35, 653-668. [CrossRef]

61. Kumar, V.B.; Vyas, K.; Buddhiraju, M.; Alshaher, M.; Flood, J.F.; Morley, J.E. Changes in membrane fatty acids and delta-9 desaturase in senescence accelerated (SAMP8) mouse hippocampus with aging. Life Sci. 1999, 65, 1657-1662. [CrossRef]

62. Gaiti, A.; Brunetti, M.; Piccinin, G.L.; Woelk, H.; Porcellati, G. The synthesis In Vivo of choline and ethanolamine phosphoglycerides in different brain areas during aging. Lipids 1982, 17, 291-296. [CrossRef] [PubMed]

63. Gaiti, A.; Sitkievicz, D.; Brunetti, M.; Porcellati, G. Phospholipid metabolism in neuronal and glial cells during aging. Neurochem. Res. 1981, 9, 1549-1558. [CrossRef]

64. Babenko, N.A.; Semenova, Y.A. Effects of exogenous phosphatidylserine on cognitive functions and phospholipid metabolism in the hippocampus of aged rats. Neurosci. Behav. Physiol. 2011, 41, 97-101. [CrossRef]

65. Kingsley, M. Effects of phosphatidylserine supplementation on exercising humans. Sports Med. 2006, 36, 657-669. [CrossRef] [PubMed]

66. McDaniel, M.A.; Maier, S.F.; Einstein, G.O. Brain-specific nutrients: A memory cure? Nutrition 2003, 19, 957-975. [CrossRef]

67. Pepeu, G.; Pepeu, I.M.; Amaducci, L. A review of phosphatidylserine pharmacological and clinical effects. Is phosphatidylserine a drug for the ageing brain? Pharmacol. Res. 1996, 33, 73-80. [CrossRef]

68. Nunzi, M.G.; Milan, F.; Guidolin, D.; Toffano, G. Dendritic spine loss in hippocampus of aged rats. Effect of brain phosphatidylserine administration. Neurobiol. Aging 1987, 8, 501-510. [CrossRef]

69. Wheeler, K.P.; Whittam, R. ATPase activity of the sodium pump needs phosphatidylserine. Nature 1970, 225, 449-450. [CrossRef] [PubMed]

70. Casamenti, F.; Scali, C.; Pepeu, G. Phosphatidylserine reverses the age-dependent decrease in cortical acetylcholine release: A microdialysis study. Eur. J. Pharmacol. 1991, 194, 11-16. [CrossRef]

71. Cohen, S.; Müller, W.E. Age-related alterations of NMDA-receptor properties in the mouse forebrain: Partial restoration by chronic phosphatidylserine treatment. Brain Res. 1992, 194, 174-180. [CrossRef]

72. Suzuki, S.; Yamatoya, H.; Sakai, M.; Kataoka, A.; Furushiro, M.; Kudo, S. Oral administration of soybean lecithin transphosphatidylated phosphatidylserine improves memory impairment in aged rats. J. Nutr. 2001, 131, 2951-2956. [CrossRef]

73. Zheng, L.; Fleith, M.; Giuffrida, F.; O’Neill, B.V.; Schneider, N. Dietary polar lipids and cognitive development: A narrative review. Adv. Nutr. 2019, 10, 1163-1176. [CrossRef]

74. Schverer, M.; O’Mahony, S.M.; O’Riordan, K.J.; Donoso, F.; Roy, B.L.; Stanton, C.; Dinan, T.G.; Schellekens, H.; Cryan, J.F. Dietary phospholipids: Role in cognitive processes across the lifespan. Neurosci. Biobehav. Rev. 2020, 111, 183-193. [CrossRef]

75. Choi, J.; Yin, T.; Shinozaki, K.; Lampe, J.W.; Stevens, J.F.; Becker, L.B.; Kim, J. Comprehensive analysis of phospholipids in the brain, heart, kidney, and liver: Brain phospholipids are least enriched with polyunsaturated fatty acids. Mol. Cell Biochem. 2018, 442, 187-201. [CrossRef]

76. Huang, Z.; Zhao, H.; Guan, W.; Liu, J.; Brennan, C.; Kulasiri, D.; Mohan, M.S. Vesicle properties and health benefits of milk phospholipids: A review. J. Food Bioact. 2019, 5, 31-42. [CrossRef]

77. Küllenberg, D.; Taylor, L.A.; Schneider, M.; Massing, U. Health effects of dietary phospholipids. Lipids Health Dis. 2012, 11, 3. [CrossRef] 
78. Wallace, T.L.; Ballard, T.M.; Glavis-Bloom, C. Animal paradigms to assess cognition with translation to humans. Cogn. Enhanc. 2015, 228, 27-57.

79. Guan, J.; MacGibbon, A.; Zhang, R.; Elliffe, D.M.; Moon, S.; Liu, D.-X. Supplementation of complex milk lipid concentrate (CMLc) improved the memory of aged rats. Nutr. Neurosci. 2015, 18, 22-29. [CrossRef] [PubMed]

80. Lee, B.; Sur, B.-J.; Han, J.-J.; Shim, I.; Her, S.; Lee, H.-J.; Hahm, D.-H. Krill phosphatidylserine improves learning and memory in Morris water maze in aged rats. Prog. Neuropsychophamacol. Biol. Psychiatry 2010, 34, 1085-1093. [CrossRef]

81. Cenacchi, T.; Bertoldin, T.; Farina, C.; Fiori, M.G.; Crepaldi, G.; Azzini, C.F.; Girardello, R.; Bagozzi, B.; Garuti, R.; Vivaldi, P.; et al. Cognitive decline in the elderly: A double-blind, placebo-controlled multicenter study on efficacy of phosphatidylserine administration. Aging Clin. Exp. Res. 1993, 5, 123-133. [CrossRef] [PubMed]

82. Engel, R.R.; Satzger, W.; Günther, W.; Kathmann, N.; Bove, D.; Gerke, S.; Münch, U.; Hippius, H. Double-blind cross-over study of phosphatidylserine vs. placebo in patients with early dementia of the Alzheimer type. Eur. Neuropsychopharmacol. 1992, 2, 149-155. [CrossRef]

83. Kanno, T.; Jin, Y.; Nishizaki, T. DL-/PO-phosphatidylcholine restores restraint stress-induced depression-related behaviors and spatial memory impairment. Behav. Pharmacol. 2014, 25, 575-581. [CrossRef] [PubMed]

84. O'Mahony, S.M.; Neufeld, K.-A.M.; Waworuntu, R.V.; Pusceddu, M.M.; Manurung, S.; Murphy, K.; Strain, C.; Laguna, M.C.; Peterson, V.L.; Stanton, C.; et al. The enduring effects of early-life stress on the microbiota-gut-brain axis are buffered by dietary supplementation with milk fat globule membrane and a prebiotic blend. Eur. J. Neurosci. 2019, 4, 1042-1058. [CrossRef]

85. Boyle, N.B.; Dye, L.; Arkbåge, K.; Thorell, L.; Frederiksen, P.; Croden, F.; Lawton, C. Effects of milk-based phospholipids on cognitive performance and subjective responses to psychosocial stress: A randomized, double-blind, placebo-controlled trial in high-perfectionist men. Nutrition 2019, 57, 183-193. [CrossRef]

86. Miller, A.L.; Pitts, F.N., Jr. Brain succinate semialdehyde dehydrogenase.-III. Activities in twenty-four regions of human brain. J. Neurochem. 1967, 14, 579-584. [CrossRef] [PubMed]

87. Zoeller, R.A.; Lake, A.C.; Nagan, N.; Gaposchkin, D.P.; Legner, M.A.; Lieberthal, W. Plasmalogens as endogenous antioxidants: Somatic cell mutants reveal the importance of the vinyl ether. Biochem. J. 1999, 338, 769-776. [CrossRef] [PubMed]

88. Jenkins, C.M.; Yang, K.; Liu, G.; Moon, S.H.; Dilthey, B.G.; Gross, R.W. Cytochrome $c$ is an oxidative stress-activated plasmalogenase that cleaves plasmenylcholine and plasmenylethanolamine at the sn-1 vinyl ether linkage. J. Biol. Chem. 2018, 293, 8693-8709. [CrossRef]

89. Ginsberg, L.; Rafique, S.; Xuereb, J.H.; Rapoport, S.I.; Gershfeld, N.L. Disease and anatomic specificity of ethanolamine plasmalogen deficiency in Alzheimer's disease brain. Brain Res. 1995, 698, 223-226. [CrossRef]

90. Wells, K.; Farooqui, A.A.; Liss, L.; Horrocks, L.A. Neural membrane phospholipids in Alzheimer disease. Neurochem. Res. 1999, 20, 1329-1333. [CrossRef]

91. Guan, Z.; Wang, Y.; Cairns, N.J.; Lantos, P.L.; Dallner, G.; Sindelar, P.J. Decrease and structural modifications of phosphatidylethanolamine plasmalogen in the brain with Alzheimer disease. J. Neuropathol. Exp. Neurol. 1999, 58, 740-747. [CrossRef] [PubMed]

92. Yamashita, S.; Honjo, A.; Aruga, M.; Nakagawa, K.; Miyazawa, T. Preparation of marine plasmalogen and selective identification of molecular species by LC-MS/MS. J. Oleo Sci. 2014, 63, 423-430. [CrossRef] [PubMed]

93. Yamashita, S.; Abe, A.; Nakagawa, K.; Kinoshita, M.; Miyazawa, T. Separation and detection of plasmalogen in marine invertebrates by high-performance liquid chromatography with evaporative light-scattering detection. Lipids 2014, 49, 1261-1273. [CrossRef]

94. Yamashita, S.; Kanno, S.; Honjo, A.; Otoki, Y.; Nakagawa, K.; Kinoshita, M.; Miyazawa, T. Analysis of plasmalogen species in foodstuffs. Lipids 2016, 51, 199-210. [CrossRef] [PubMed]

95. Fujino, T.; Hossain, M.S.; Mawatari, S. Therapeutic efficacy of plasmalogens for Alzheimer's disease, mild cognitive impairment, and Parkinson's disease in conjunction with a new hypothesis for the etiology of Alzheimer's disease. Adv. Exp. Med. Biol. 2020, 1299, 195-212.

96. Hara, H.; Wakisaka, T.; Aoyama, Y. Lymphatic absorption of plasmalogen in rats. Br. J. Nutr. 2003, 90, 29-32. [CrossRef] [PubMed]

97. Nishimukai, M.; Wakisaka, T.; Hara, H. Ingestion of plasmalogen markedly increased plasmalogen levels of blood plasma in rats. Lipids 2003, 38, 1227-1235. [CrossRef] [PubMed]

98. Dyall, S.C.; Michael-Titus, A.T. Neurological benefits of omega-3 fatty acids. Neuromolecular Med. 2008, 10, 219-235. [CrossRef]

99. Ryan, A.S.; Astwood, J.D.; Gautier, S.; Kuratko, C.N.; Nelson, E.B.; Salem, N., Jr. Effects of long-chain polyunsaturated fatty acid supplementation on neurodevelopment in childhood: A review of human studies. Prostaglandins Leukot. Essent. Fatty Acids 2010, 82, 305-314. [CrossRef]

100. Nilsson, A.; Radeborg, K.; Salo, I.; Björck, I. Effect of supplementation with n-3 polyunsaturated fatty acids on cognitive performance and cardiometabolic risk markers in healthy 51 to 72 years old subjects: A randomized controlled cross-over study. Nutr. J. 2012, 11, 99. [CrossRef] [PubMed]

101. Conquer, J.A.; Tierney, M.C.; Zecevic, J.; Bettger, W.J.; Fisher, R.H. Fatty acid analysis of blood plasma of patients with Alzheimer's disease, other types of dementia and cognitive impairment. Lipids 2000, 35, 1305-1312. [CrossRef]

102. Kalmijn, S.; van Boxtel, P.J.; Ocké, M.; Verschuren, W.M.M.; Kromhout, D.; Launer, L.J. Dietary intake of fatty acids and fish in relation to cognitive performance at middle age. Neurology 2004, 62, 275-280. [CrossRef] 
103. Heude, B.; Ducimetiére, P.; Berr, C. Cognitive decline and fatty acid composition of erythrocyte membranes-The EVA study. Am. J. Clin. Nutr. 2003, 77, 803-808. [CrossRef]

104. Kalmijn, S.; Feskens, E.J.M.; Launer, L.J.; Kromhout, D. Polyunsaturated fatty acids, antioxidants, and cognitive function in very old men. Am. J. Epidemiol. 1997, 145, 33-41. [CrossRef]

105. Beydoun, M.A.; Kaufman, J.S.; Satia, J.A.; Rosamond, W.; Folsom, A.R. Plasma n-3 fatty acids and the risk of cognitive decline in older adults: The atherosclerosis risk in communities study. Am. J. Clin. Nutr. 2007, 85, 1103-1111. [CrossRef]

106. Dullemeijer, C.; Durga, J.; Brouwer, I.A.; van de Rest, O.; Kok, F.J.; Brummer, R.-J.M.; van Boxtel, M.P.J.; Verhoef, P. n-3 fatty acid proportions in plasma and cognitive performance in older adults. Am. J. Clin. Nutr. 2007, 86, 1479-1485. [CrossRef]

107. Dangour, A.D.; Allen, E.; Elbourne, D.; Fletcher, A.; Richards, M.; Uauy, R. Fish consumption and cognitive function among older people in the UK: Baseline data from the OPAL study. J. Nutr. Health Aging 2009, 13, 198-202. [CrossRef] [PubMed]

108. Morris, M.C.; Evans, D.A.; Tangney, C.C.; Bienias, J.L.; Wilson, R.S. Fish consumption and cognitive decline with age in a large community study. Arch. Neurol. 2005, 62, 1849-1853. [CrossRef]

109. van Gelder, B.M.; Tijhuis, M.; Kalmijn, S.; Kromhout, D. Fish consumption, n-3 fatty acids, and subsequent 5-y cognitive decline in elderly men: The Zutphen Elderly Study. Am. J. Clin. Nutr. 2007, 85, 1142-1147. [CrossRef] [PubMed]

110. Eskelinen, M.H.; Ngandu, T.; Helkala, E.-L.; Tuomilehto, J.; Nissinen, A.; Soininen, H.; Kivipelto, M. Fat intake at midlife and cognitive impairment later in life: A population-based CAIDE study. Int. J. Geriatr. Psychiatry 2008, 23, 741-747. [CrossRef]

111. Nurk, E.; Drevon, C.A.; Refsum, H.; Solvoll, K.; Vollset, S.E.; Nygård, O.; Nygaard, H.A.; Engedal, K.; Tell, G.S.; Smith, A.D. Cognitive performance among the elderly and dietary fish intake: The Hordaland health study. Am. J. Clin. Nutr. 2007, 86, 1470-1478. [CrossRef] [PubMed]

112. Centers for Disease, Control, and Prevention. National Health and Nutrition Examination Survey. Survey Methods and Analytic Guidelines. Available online: https:/ / www.cdc.gov/nchs/nhanes/index (accessed on 15 January 2020).

113. Centers for Disease, Control, and Prevention. National Health and Nutrition Examination Survey. Questionnaires, Datasets, and Related Documentation. Available online: https://www.cdc.gov/nchs (accessed on 15 January 2020).

114. Dong, X.; Li, S.; Chen, J.; Li, Y.; Wu, Y.; Zhang, D. Association of dietary $\omega-3$ and $\omega-6$ fatty acids intake with cognitive performance in older adults: National health and nutrition examination survey (NHANES) 2011-2014. Nutr. J. 2020, 19, 25. [CrossRef]

115. Kivipelto, M.; Helkala, E.-L.; Laakso, M.P.; Hänninen, T.; Hallikainen, M.; Alhainen, K.; Iivonen, S.; Mannermaa, A.; Tuomilehto, J.; Nissinen, A.; et al. Apolipoprotein E $\varepsilon 4$ allele, elevated midlife total cholesterol level, and high midlife systolic blood pressure are independent risk factors for late-life Alzheimer disease. Ann. Intern. Med. 2002, 137, 149-155. [CrossRef]

116. Notkola, I.L.; Sulkava, R.; Pekkanen, J.; Erkinjuntti, T.; Ehnholm, C.; Kivinen, P.; Tuomilehto, J.; Nissinen, A. Serum total cholesterol, apolipoprotein E $\varepsilon 4$ allele, and Alzheimer's disease. Neuroepidemiology 1998, 17, 14-20. [CrossRef] [PubMed]

117. Solomon, A.; Kivipelto, M.; Wolozin, B.; Whitmer, R.A. Midlife serum cholesterol and increased risk of Alzheimer's and vascular dementia three decades later. Dement. Geriatr. Cogn. Disord. 2009, 28, 75-80. [CrossRef] [PubMed]

118. Whitmer, R.A.; Sidney, S.; Selby, J.; Johnston, S.C.; Yaffe, K. Midlife cardiovascular risk factors and risk of dementia in late life. Neurology 2005, 64, 277-281. [CrossRef]

119. Mielke, M.M.; Zandi, P.P.; Shao, H.; Waern, M.; Östling, S.; Guo, X.; Björkelund, C.; Lissner, L.; Skoog, I.; Gustafson, D.R. The 32-year relationship between cholesterol and dementia from midlife to late life. Neurology 2010, 75, 1888-1895. [CrossRef] [PubMed]

120. Kalmijn, S.; Foley, D.; White, L.; Burchfiel, C.M.; Curb, J.D.; Petrovitch, H.; Ross, G.W.; Havlik, R.J.; Launer, L.J. Metabolic cardiovascular syndrome and risk of dementia in Japanese-American elderly men. The Honolulu-Asia aging study. Arterioscler. Thromb. Vasc. Biol. 2000, 20, 2255-2260. [CrossRef] [PubMed]

121. Stewart, R.; White, L.R.; Xue, Q.-L.; Launer, L.J. Twenty-six-year change in total cholesterol levels and incident dementia: The Honolulu-Asia aging study. Arch. Neurol. 2007, 64, 103-107. [CrossRef] [PubMed]

122. Tan, Z.S.; Seshadri, S.; Beiser, A. Plasma total cholesterol level as a risk factor for Alzheimer disease: The framingham study. Arch. Intern. Med. 2003, 163, 1053-1057. [CrossRef]

123. Anstey, K.J.; Lipnicki, D.M.; Low, L.-F. Cholesterol as a risk factor for dementia and cognitive decline: A systematic review of prospective studies with meta-analysis. Am. J. Geriatr. Psychiatry 2008, 16, 343-354. [CrossRef]

124. Mielke, M.M.; Zandi, P.P.; Sjögren, M.; Gustafson, D.; Östling, S.; Steen, B.; Skoog, I. High total cholesterol levels in late life associated with a reduced risk of dementia. Neurology 2005, 64, 1689-1695. [CrossRef]

125. Reitz, C.; Tang, M.-X.; Luchsinger, J.; Mayeux, R. Relation of plasma lipids to Alzheimer disease and vascular dementia. Arch. Neurol. 2004, 61, 705-714. [CrossRef]

126. Cheng, Y.; Jin, Y.; Unverzagt, F.W.; Su, L.; Yang, L.; Ma, F.; Hake, A.M.; Kettler, C.; Chen, C.; Liu, J.; et al. The relationship between cholesterol and cognitive function is homocysteine-dependent. Clin. Interv. Aging 2014, 9, 1823-1829.

127. Miyake, Y.; Sasaki, S.; Tanaka, K.; Fukushima, W.; Kiyohara, C.; Tsuboi, Y.; Yamada, T.; Oeda, T.; Miki, T.; Kawamura, N.; et al. Dietary fat intake and risk of Parkinson's disease: A case-control study in Japan. J. Neurol. Sci. 2010, 288, 117-122. [CrossRef] [PubMed]

128. Kamanna, V.S.; Kashyap, M.L. Mechanism of action of niacin. Am. J. Cardiol. 2008, 101, S20-S26. [CrossRef] [PubMed]

129. Park, J.-H.; Lee, C.-w.; Nam, M.-J.; Kim, H.; Kwon, D.-Y.; Yoo, J.-W.; Lee, K.N.; Han, K.; Jung, J.-H.; Park, Y.-G.; et al. Association of high-density lipoprotein cholesterol variability and the risk of developing Parkinson disease. Neurology $2021,96$. 
130. Cutler, R.G. Carotenoids and retinol: Their possible importance in determining longevity of primate species. Proc. Natl. Acad. Sci. USA 1984, 81, 7627-7631. [CrossRef]

131. Akbaraly, N.T.; Faure, H.; Gourlet, V.; Favier, A.; Berr, C. Plasma carotenoid levels and cognitive performance in an elderly population: Results of the EVA study. J. Gerontol. 2007, 62A, 308-316. [CrossRef] [PubMed]

132. Stahl, W.; Sies, H. Lycopene: A biologically important carotenoid for humans? Arch. Biochem. Biophys. 1996, 336, 1-9. [CrossRef] [PubMed]

133. Paiva, S.A.; Russell, R.M. $\beta$-carotene and other carotenoids as antioxidants. J. Am. Coll. Nutr. 1999, 18, 426-433. [CrossRef]

134. Berr, C.; Balansard, B.; Arnaud, J.; Roussel, A.-M.; Alpérovitch, A. Cognitive decline is associated with systemic oxidative stress: The EVA study. Etude du Vieillissement Arteriel. J. Am. Geriatr. Soc. 2000, 48, 1285-1291. [CrossRef]

135. Gray, S.L.; Hanlon, J.T.; Landerman, L.R.; Artz, M.; Schmader, K.E.; Fillenbaum, G.G. Is antioxidant use protective of cognitive function in the community-dwelling elderly? Am. J. Geriatr. Pharmacother. 2003, 1, 3-10. [CrossRef]

136. Jama, J.W.; Launer, L.J.; Witteman, J.C.M.; den Breeijen, J.H.; Breteler, M.M.B.; Grobbee, D.E.; Hofman, A. Dietary antioxidants and cognitive function in a population-based sample of older persons. The Rotterdam study. Am. J. Epidemiol. 1996, 144, 275-280. [CrossRef]

137. Morris, M.C.; Evans, D.A.; Bienias, J.L.; Tangney, C.C.; Wilson, R.S. Vitamin E and cognitive decline in older persons. Arch. Neurol. 2002, 59, 1125-1132. [CrossRef]

138. Perrig, W.J.; Perrig, P.; Stähelin, H.B. The relation between antioxidants and memory performance in the old and very old. J. Am. Geriatr. Soc. 1997, 45, 718-724. [CrossRef]

139. Smith, A.; Clark, R.; Nutt, D.; Haller, J.; Hayward, S.; Perry, K. Anti-oxidant vitamins and mental performance of the elderly. Hum. Psychopharmacol. 1999, 14, 459-471. [CrossRef]

140. Age-Related Eye Disease Study Research Group Impact of antioxidants, zinc, and copper on cognition in the elderly: A randomized, controlled trial. Neurology 2004, 63, 1705-1707. [CrossRef] [PubMed]

141. Stahl, W.; Junghans, A.; de Boer, B.; Drionina, E.S.; Briviba, K.; Sies, H. Carotenoid mixtures protect multilamellar liposomes against oxidative damage: Synergistic effects of lycopene and lutein. FEBS Lett. 1998, 427, 305-308. [CrossRef]

142. Woodall, A.A.; Britton, G.; Jackson, M.J. Carotenoids and protection of phospholipids in solution or in liposomes against oxidation by peroxyl radicals: Relationship between carotenoid structure and protective ability. Biochim. Biophys. Acta. 1997, 1336, 575-586. [CrossRef]

143. Johnson, E.J. Role of lutein and zeaxanthin in visual and cognitive function throughout the lifespan. Nutr. Rev. 2014, 72, 605-612. [CrossRef]

144. Johnson, E.J. A possible role for lutein and zeaxanthin in cognitive function in the elderly. Am. J. Clin. Nutr. 2012, 96, 1161S-1165S. [CrossRef] [PubMed]

145. Nakagawa, K.; Kiko, T.; Miyazawa, T.; Sookwong, P.; Tsuduki, T.; Satoh, A.; Miyazawa, T. Amyloid $\beta$-induced erythrocytic damage and its attenuation by carotenoids. FEBS Lett. 2011, 585, 1249-1254. [CrossRef]

146. Nakagawa, K.; Kiko, T.; Miyazawa, T.; Burdeos, G.C.; Kimura, F.; Satoh, A.; Miyazawa, T. Antioxidant effect of astaxanthin on phospholipid peroxidation in human erythrocytes. Br. J. Nutr. 2011, 105, 1563-1571. [CrossRef]

147. Sevilla, J.M.; Fernández, F.G.; Grima, E.M. Biotechnological production of lutein and its application. Appl. Microbiol. Biotech. 2010, 86, 27-40. [CrossRef]

148. Shi, X.-M.; Zhang, X.W.; Chen, F. Heterotrophic production of biomass and lutein by chlorella protothecoides on various nitrogen sources. Enzym. Microb. Technol. 2000, 27, 312-318. [CrossRef]

149. Miyazawa, T.; Nakagawa, K.; Kumura, F.; Nakashima, Y.; Maruyama, I.; Higuchi, O.; Miyazawa, T. Chlorella is an effective dietary source of lutein for human erythrocytes. J. Oleo Sci. 2013, 62, 773-779. [CrossRef] [PubMed]

150. Mecocci, P.; Polidori, M.C.; Troiano, L.; Cherubini, A.; Cecchetti, R.; Pini, G.; Straatman, M.; Monti, D.; Stahl, W.; Sies, H.; et al. Plasma antioxidants and longevity: A study on healthy centenarians. Free Radic. Biol. Med. 2000, 28, 1243-1248. [CrossRef]

151. Travica, N.; Ried, K.; Sali, A.; Scholey, A.; Hudson, I.; Pipingas, A. Vitamin C status and cognitive function: A systematic review. Nutrients 2017, 9, 960. [CrossRef]

152. Rinaldi, P.; Polidori, M.C.; Metastasio, A.; Mariani, E.; Mattioli, P.; Cherubini, A.; Catani, M.; Cecchetti, R.; Senin, U.; Mecocci, P. Plasma antioxidants are similarly depleted in mild cognitive impairment and in Alzheimer's disease. Neurobiol. Aging 2003, 24, 915-919. [CrossRef]

153. Rivière, S.; Birlouez-Aragon, I.; Nourhashémi, F.; Vellas, B. Low plasma vitamin C in Alzheimer patients despite an adequate diet. Int. J. Geriat. Psychiatry 1998, 13, 749-754. [CrossRef]

154. Polidori, M.C.; Patrizia, M. Plasma susceptibility to free radical-induced antioxidant consumption and lipid peroxidation is increased in very old subjects with Alzheimer disease. J. Alzheimer's Dis. 2002, 4, 517-522. [CrossRef]

155. Burton, G.W.; Joyce, A.; Ingold, K.U. First proof that vitamin E is major lipid-soluble, chain-breaking antioxidant in human blood plasma. Lancet 1982, 2, 327. [CrossRef]

156. Burton, G.W.; Joyce, A.; Ingold, K.U. Is vitamin E the only lipid-soluble, chain-breaking antioxidant in human blood plasma and erythrocyte membranes? Arch. Biochem. Biophys. 1983, 221, 281-290. [CrossRef]

157. Miyazawa, T.; Burdeos, G.C.; Itaya, M.; Nakagawa, K.; Miyazawa, T. Vitamin E: Regulatory redox interactions. IUBMB Life 2019, 71, 430-441. [CrossRef]

158. Joshi, Y.B.; Pratico, D. Vitamin E in aging, dementia, and Alzheimer's disease. BioFactors 2012, 38, 90-97. [CrossRef] 
159. Olson, C.R.; Mello, C.V. Significance of vitamin A to brain function, behavior and learning. Mol. Nutr. Food Res. $2010,54,489-495$. [CrossRef]

160. Harrison, P.J.; Weinberger, D.R. Schizophrenia genes, gene expression, and neuropathology: On the matter of their convergence. Mol. Phychiatry 2005, 10, 40-68. [CrossRef] [PubMed]

161. Gómez-Pinilla, F. Brain foods: The effects of nutrients on brain function. Nat. Rev. Neurosci. 2008, 9, 568-578. [CrossRef]

162. Pallet, V.; Touyarot, K. Vitamin A and cognitive processes. Nutr. Healthy Aging 2015, 3, 21-31. [CrossRef]

163. Polidori, M.C.; Mariani, E.; Baggio, G.; Deiana, L.; Carru, C.; Pes, G.M.; Cecchetti, R.; Franceschi, C.; Senin, U.; Mecocci, P. Different antioxidant profiles in Italian centenarians: The Sardinian peculiarity. Eur. J. Clin. Nutr. 2007, 61, 922-924. [CrossRef] [PubMed]

164. Feng, L.; Li, J.; Yap, K.-B.; Kua, E.-H.; Ng, T.-P. Vitamin B-12, apolipoprotein E genotype, and cognitive performance in community-living older adults: Evidence of a gene-micronutrient interaction. Am. J. Clin. Nutr. 2009, 89, 1263-1268. [CrossRef]

165. Riggs, K.M.; Spiro, A., 3rd; Tucker, K.; Rush, D. Relation of vitamin B-12, vitamin B-6, folate and homocysteine to cognitive performance in the normative aging study. Am. J. Clin. Nutr. 1996, 63, 306-314. [CrossRef] [PubMed]

166. Meehan, M.; Penckofer, S. The role of vitamin D in the aging adult. J. Aging Gerontol. 2014, 2, 60-71. [CrossRef] [PubMed]

167. Goodwill, A.M.; Szoeke, C.A. systematic review and meta-analysis of the effect of low vitamin D on cognition. J. Am. Geriatr. Soc. 2017, 65, 2161-2168. [CrossRef]

168. Presse, N.; Belleville, S.; Gaudreau, P.; Greenwood, C.E.; Kergoat, M.-J.; Morais, J.A.; Payette, H.; Shatenstein, B.; Ferland, G. Vitamin K status and cognitive function in healthy older adults. Neurobiol. Aging 2013, 34, 2777-2783. [CrossRef]

169. Fullard, M.E.; Duda, J.E. A review of the relationship between vitamin D and Parkinson disease symptoms. Front. Neurol. 2020, 11, 454. [CrossRef]

170. Vauzour, D.; Camprubi-Robles, M.; Miquel-Kergoat, S.; Andres-Lacueva, C.; Bánáti, D.; Barberger-Gateau, P.; Bowman, G.L.; Caberlotto, L.; Clarke, R.; Hogervorst, E.; et al. Nutrition for the ageing brain: Towards evidence for an optimal diet. Ageing Res. Rev. 2017, 35, 222-240. [CrossRef]

171. Vauzour, D. Dietary polyphenols as modulators of brain functions: Biological actions and molecular mechanisms underpinning their beneficial effects. Oxid. Med. Cell. Longev. 2012, 2012, 914273. [CrossRef] [PubMed]

172. Ammar, A.; Trabelsi, K.; Müller, P.; Bouaziz, B.; Boukhris, O.; Glenn, J.M.; Bott, N.; Driss, T.; Chtourou, H.; Müller, N.; et al. The effect of (poly)phenol-rich interventions on cognitive functions and neuroprotective measures in healthy aging adults: A systematic review and meta-analysis. J. Clin. Med. 2020, 9, 835. [CrossRef] [PubMed]

173. Lamport, D.J.; Dye, L.; Wightman, J.D.; Lawton, C.L. The effects of flavonoid and other polyphenol consumption on cognitive performance: A systematic research review of human experimental and epidemiological studies. Nutr. Aging 2012, 1, 5-25. [CrossRef]

174. Mastroiacovo, D.; Kwik-Uribe, C.; Grassi, D.; Necozinoe, S.; Raffaele, A.; Pistacchio, L.; Righetti, R.; Bocale, R.; Lechiara, M.C.; Marini, C.; et al. Cocoa flavanol consumption improves cognitive function, blood pressure control, and metabolic profile in elderly subjects: The cocoa, cognition, and aging (cocoa) study-a randomized controlled trial. Am. J. Clin. Nutr. 2015, 101, 538-548. [CrossRef]

175. Whyte, A.R.; Cheng, N.; Fromentin, E.; Williams, C.M. A randomized, double-blinded, placebo-controlled study to compare the safety and efficacy of low dose enhanced wild blueberry powder and wild blueberry extract (thinkblue ${ }^{\mathrm{TM}}$ ) in maintenance of episodic and working memory in older adults. Nutrients 2018, 10, 660. [CrossRef] [PubMed]

176. Wightman, E.L.; Jackson, P.A.; Khan, J.; Forster, J.; Heiner, F.; Feistel, B.; Suarez, C.G.; Pischel, I.; Kennedy, D.O. The acute and chronic cognitive and cerebral blood flow effects of a sidertisscardica (Greek mountain tea) extract: A double blind, randomized, placebo controlled, parallel groups study in healthy humans. Nutrients 2018, 10, 955. [CrossRef] [PubMed]

177. Witte, A.V.; Kerti, L.; Margulies, D.S.; Flöel, A. Effects of resveratrol on memory performance, hippocampal functional connectivity, and glucose metabolism in healthy older adults. J. Neurosci. 2014, 34, 7862-7870. [CrossRef]

178. Lamport, D.J.; Pal, D.; Moutsiana, C.; Field, D.T.; Williams, C.M.; Spencer, J.P.E.; Butler, L.T. The effect of flavanol-rich cocoa on cerebral perfusion in healthy older adults during conscious resting state: A placebo controlled, crossover, acute trial. Psychopharmacology 2015, 232, 3227-3234. [CrossRef]

179. Bowtell, J.L.; Aboo-Bakkar, Z.; Conway, M.E.; Adlam, A.-L.R.; Fulford, J. Enhanced task-related brain activation and resting perfusion in healthy older adults after chronic blueberry supplementation. Appl. Physiol. Nutr. Metab. 2017, 42, 773-779. [CrossRef]

180. Ho, K.K.; Ferruzzi, M.G.; Wightman, J.D. Potential health benefits of (poly) phenols derived from fruit and $100 \%$ fruit juice. Nutr. Rev. 2020, 78, 145-174. [CrossRef] [PubMed]

181. Cui, C.; Birru, R.L.; Snitz, B.E.; Ihara, M.; Kakuta, C.; Lopresti, B.J.; Aizenstein, H.J.; Lopez, O.L.; Mathis, C.A.; Miyamoto, Y.; et al. Effects of soy isoflavones on cognitive function: A systematic review and meta-analysis of randomized controlled trials. Nutr. Rev. 2020, 78, 134-144. [CrossRef]

182. Holland, T.M.; Agarwal, P.; Wang, Y.; Leurgans, S.E.; Bennett, D.A.; Booth, S.L.; Morris, M.C. Dietary flavonols and risk of Alzheimer dementia. Neurology 2020, 94. [CrossRef]

183. Gleason, C.E.; Carlsson, C.M.; Barnet, J.H.; Meade, S.A.; Setchell, K.D.; Atwood, C.S.; Johnson, S.C.; Ries, M.L.; Asthana, S. A preliminary study of the safety, feasibility and cognitive efficacy of soy isoflavone supplements in older men and women. Age Ageing 2009, 38, 86-93. [CrossRef] 
184. Howes, J.B.; Bray, K.; Lorenz, L.; Smerdely, P.; Howes, L.G. The effects of dietary supplementation with isoflavones from red clover on cognitive function in postmenopausal women. Climacteric 2004, 7, 70-77. [CrossRef] [PubMed]

185. Marsh, C.E.; Carter, H.H.; Guelfi, K.J.; Smith, K.J.; Pike, K.E.; Naylor, L.H.; Green, D.J. Brachial and cerebrovascular functions are enhanced in postmenopausal women after ingestion of chocolate with a high concentration of cocoa. J. Nutr. 2017, 147, 1686-1692. [CrossRef]

186. Sarker, M.R.; Franks, S.F. Efficacy of curcumin for age-associated cognitive decline: A narrative review of preclinical and clinical studies. GeroScience 2018, 40, 73-95. [CrossRef] [PubMed]

187. Voulgaropoulou, S.D.; van Amelsvoort, T.A.M.J.; Prickaerts, J.; Vingerhoets, C. The effect of curcumin on cognition in Alzheimer's disease and healthy aging: A systematic review of pre-clinical and clinical studies. Brain Res. 2019, 1725, 146476. [CrossRef] [PubMed]

188. Baum, L.; Lam, C.W.K.; Cheung, S.K.-K.; Kwok, T.; Lui, V.; Tsoh, J.; Lam, L.; Leung, V.; Hui, E.; Ng, C.; et al. Six-month randomized, placebo-controlled, double-blind, pilot clinical trial of curcumin in patients with Alzheimer disease. J. Clin. Psychopharmacol. 2008, 28, 110-113. [CrossRef] [PubMed]

189. Ringman, J.M.; Frautschy, S.A.; Teng, E.; Begum, A.N.; Bardens, J.; Beigi, M.; Gylys, K.H.; Badmaev, V.; Heath, D.D.; Apostolova, L.G.; et al. Oral curcumin for Alzheimer's disease: Tolerability and efficacy in a 24-week randomized, double blind, placebocontrolled study. Alzheimer's Res. Ther. 2012, 4, 43. [CrossRef] [PubMed]

190. Cox, K.H.M.; Pipingas, A.; Scholey, A.B. Investigation of the effects of solid lipid curcumin on cognition and mood in a healthy older population. J. Psychopharmacol. 2015, 29, 642-651. [CrossRef]

191. Rainey-Smith, S.R.; Brown, B.M.; Sohrabi, H.R.; Shah, T.; Goozee, K.G.; Gupta, V.B.; Martins, R.N. Curcumin and cognition: A randomized, placebo-controlled, double-blind study of community-dwelling older adults. Br. J. Nutr. 2016, 115, $2106-2113$. [CrossRef]

192. Small, G.W.; Siddarth, P.; Li, Z.; Miller, K.J.; Ercoli, L.; Emerson, N.D.; Martinez, J.; Wong, K.-P.; Liu, J.; Merrill, D.A.; et al. Memory and brain amyloid and tau effects of a bioavailable form of curcumin in non-demented adults: A double-blind, placebo-controlled 18-month trial. Am. J. Geriatr. Psychiatry 2018, 26, 266-277. [CrossRef]

193. Miyazawa, T.; Nakagawa, K.; Kim, S.H.; Thomas, M.J.; Paul, L.; Zingg, J.-M.; Dolnikowski, G.G.; Roberts, S.B.; Kimura, F.; Miyazawa, T.; et al. Curcumin and piperine supplementation of obese mice under caloric restriction modulates body fat and interleukin-1ß. Nutr. Metab. 2018, 15, 12. [CrossRef] [PubMed]

194. Harigae, T.; Nakagawa, K.; Miyazawa, T.; Inoue, N.; Kimura, F.; Ikeda, I.; Miyazawa, T. Metabolic fate of poly-(lactic-co-glycolic acid)-based curcumin nanoparticles following oral administration. Int. J. Nanomed. 2016, 11, 3009-3022.

195. Shoji, M.; Nakagawa, K.; Watanabe, A.; Tsuduki, T.; Yamada, T.; Kuwahara, S.; Kimura, F.; Miyazawa, T. Comparison of the effects of curcumin and curcumin glucuronide in human hepatocellular carcinoma HepG2 cells. Food Chem. 2014, 151, 126-132. [CrossRef]

196. Choudhury, A.K.; Raja, S.; Mahapatra, S.; Nagabhushanam, K.; Majeed, M. Synthesis and evaluation of the anti-oxidant capacity of curcumin glucuronides, the major curcumin metabolites. Antioxidants 2015, 4, 750-767. [CrossRef] [PubMed]

197. Findeis, M.A. The role of amyloid $\beta$ peptide 42 in Alzheimer's disease. Pharmacol. Ther. 2007, 116, 266-286. [CrossRef]

198. Akazawa, N.; Hamasaki, A.; Tanahashi, K.; Kosaki, K.; Yoshikawa, T.; Myoenzono, K.; Maeda, S. Lactotripeptide ingestion increases cerebral blood flow velocity in middle-aged and older adults. Nutr. Res. 2018, 53, 61-66. [CrossRef] [PubMed]

199. Min, L.-J.; Kobayashi, Y.; Mogi, M.; Tsukuda, K.; Yamada, A.; Yamauchi, K.; Abe, F.; Iwanami, J.; Xiao, J.-Z.; Horiuchi, M. Administration of bovine casein-derived peptide prevents cognitive decline in Alzheimer disease model mice. PLoS ONE 2017, 12, e0171515. [CrossRef]

200. Yuda, N.; Tanaka, M.; Yamauchi, K.; Abe, F.; Kakiuchi, I.; Kiyosawa, K.; Miyasaka, M.; Sakane, N.; Nakamura, M. Effect of the casein-derived peptide Met-Lys-Pro on cognitive function in community-dwelling adults without dementia: A randomized double-blind, placebo-controlled trial. Clin. Interv. Aging 2020, 15, 743-754. [CrossRef]

201. Wade, A.M.; Tucker, H.N. Antioxidant characteristics of L-histidine. J. Nutr. Biochem. 1998, 9, 308-315. [CrossRef]

202. Masuoka, N.; Lei, C.; Li, H.; Hisatsune, T. Influence of imidazole-dipeptides on cognitive status and preservation in elders: A narrative review. Nutrients 2021, 13, 397. [CrossRef] [PubMed]

203. Fonteh, A.N.; Harrington, R.J.; Tsai, A.; Liao, P.; Harrington, M.G. Free amino acid and dipeptide changes in the body fluids from Alzheimer's disease subjects. Amino Acids 2007, 32, 213-224. [CrossRef]

204. Dringen, R.; Gutterer, J.M.; Hirrlinger, J. Glutathione metabolism in brain. Eur. J. Biochem. 2000, 267, 4912-4916. [CrossRef]

205. Ozawa, H.; Hirayama, A.; Ishikawa, T.; Kudo, R.; Maruyama, M.; Shoji, F.; Doke, T.; Ishimoto, T.; Maruyama, S.; Soga, T.; et al. Comprehensive dipeptide profiling and quantitation by capillary electrophoresis and liquid chromatography coupled with tandem mass spectrometry. Anal. Chem. 2020, 92, 9799-9806. [CrossRef]

206. Ozawa, H.; Hirayama, A.; Shoji, F.; Maruyama, M.; Suzuki, K.; Yamanaka-Okumura, H.; Tatano, H.; Morine, Y.; Soga, T.; Shimada, M.; et al. Comprehensive dipeptide analysis revealed cancer-specific profile in the liver of patients with hepatocellular carcinoma and hepatitis. Metabolites 2020, 10, 442. [CrossRef]

207. Glenn, J.M.; Madero, E.N.; Bott, N.T. Dietary protein and amino acid intake: Links to the maintenance of cognitive health. Nutrients 2019, 11, 1315. [CrossRef] [PubMed]

208. Penland, J.G. Dietary boron, brain function, and cognitive performance. Environ. Health Perspect. 1994, 102, 65-72. [PubMed] 
209. Kelly, J.; Fulford, J.; Vanhatalo, A.; Blackwell, J.R.; French, O.; Bailey, S.J.; Gilchrist, M.; Winyard, P.G.; Jones, A.M. Effects of short-term dietary nitrate supplementation on blood pressure, $\mathrm{O}_{2}$ uptake kinetics and muscle and cognitive function in older adults. Am. J. Physiol. Regul. Integr. Comp. Physiol. 2013, 304, R73-R83. [CrossRef]

210. Stanaway, L.; Rutherfurd-Markwick, K.; Page, R.; Ali, A. Performance and health benefits of dietary nitrate supplementation in older adults: A systematic review. Nutrients 2017, 9, 1171. [CrossRef]

211. Nehlig, A. Is caffeine a cognitive enhancer? J. Alzheimer's Dis. 2010, 20, S85-S94. [CrossRef] [PubMed]

212. Jarvis, M.J. Does caffeine intake enhance absolute levels of cognitive performance? Psychopharmacology 1993, 110, 45-52. [CrossRef] [PubMed]

213. Torga, G.N.; Spers, E.E. Chapter 2-Perspectives of global coffee demand. In Coffee Consumption and Industry Strategies in Brazil; Woodhead Publishing: Sawston, UK, 2020; pp. 21-49. 